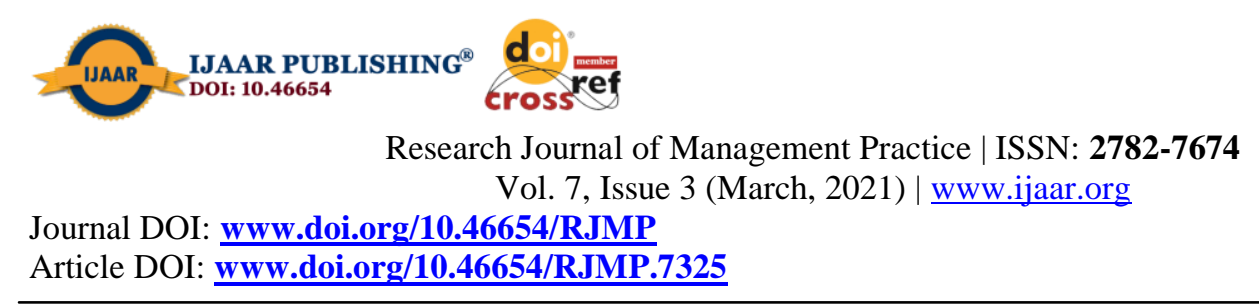

\title{
ELECTRONIC PAYMENT PRODUCT AND QUOTED DEPOSIT MONEY BANKS PERFORMANCE IN NIGERIA
}

\author{
Momoh-Musa, A \\ Department of Accounting, Faculty of Management Sciences, University Port Harcourt, \\ Choba, Port Harcourt. \\ E-mail: Aminice577@gmail.com
}

\section{Dr. U. I. Ironkwe}

Department of Accounting, Faculty of Management Sciences, University Port Harcourt,

Choba, Port Harcourt.

\begin{abstract}
Efficient payment systems are crucial for developed and less developing countries economic development and are regarded as the backbone to a highly competitive country. Innovations in the payment industry have also lead to greater access to formal financial system. This study examined the relationship between electronic payment product and quoted deposit money banks performance in Nigeria. data on different sub-variables of electronic payment product and return on equity from 2007-2018 were collected from Central Bank of Nigeria statistical bulletin, annual Central Bank of Nigeria reports, federal Inland Revenue Service, annual reports and e-business unit report of deposit money banks. Ordinary Least Square of multivariate regression based on Auto-regressive distributed Lag, unit root test, panel cointegration, granger causality and panel dynamic error correction model was used in analyzing the data. The empirical results indicate that electronic payment product significantly relate to return on equity. We conclude that electronic payment product has the potency to make positive and significant contribution to performance and recommends that Automated Teller Machine (ATM) should be put in different locations for easily accessible by customers, so that quick service and convenience is maintained hence improving bank operations to the same time constant service should be ensured in order to provide reliability of the services. Deposit money banks and other specialized organizations should conduct awareness programs for client son the importance and ease of using electronic payment products in financial transactions in local and international markets. Banks should pay attention to issuing new and modern electronic payment methods to attract new customers and fellow developments in global markets.
\end{abstract}

Keywords: Point of Sale, Automated Teller Machine, Return on Equity, Performance and quoted Deposit Banks. 


\section{Introduction}

Electronic payment has become the most acceptable means of payments in today's financial transactions across the world. This is due to its efficiency (Abbasi \& Weigand, 2017), convenience (Agwu, 2018), timeliness (Gerpott, 2018), security (Gathina, 2018), reliability (Gerpoth, 2018), scalability (Rebia., Ladan; Usman \& Garba, 2019), anonymity (Ibanichuka \& Oko, 2019), acceptability (Jumba \& Wepukhulu). For this reason, electronic payment studies had attracted different scholars around the globe and conducted in different parts of the world to examine the extent of electronic payment system adoption and the influencing factors that leads to its adoption at both individuals and organizational levels (Akinlo \& Adebayo 2013; Akhisar., Tunya \& Tunay, 2015; Chalomba \& Gujral, 2016; Kosse., Cheu., Fett., Jiongo., Nield \& Welte, 2017; Le., Vu., Du \& Tran, 2018; Ogutu \& Fatoki, 2019). Thomas and Angus (2013) find the combination of demographic and financial characteristics, detailed supply-side factors, and new technology adoption in a single analysis are unique where e-payments are concerned. Further, transaction cost is found to have the greatest effect on the adoption of e-payments as perceived by the consumer. Credit transfer is by far the most commonly used payment medium in Belgium. The use of cheques, as an e-payment instrument, has been declining steadily as commercial banks gradually increased cheque fees. Buyers have turned out to be mindful of the benefits of cashless installments and as their acknowledgment of these installments builds, an ascent in the supply of products and enterprises that can be purchased through the cashless stage is normal (Upadhyay \& Jahanyan, 2016). It very well may be said about the future, that cashless installments will most likely be unable to substitute the customary physical wallet and may along these lines simply supplement existing installment arrangements (Solat, 2017). However, it is additionally a probability that a substitution will happen bit by bit and first following quite a long while be finished Shukla (2017). Regardless of what will occur, investigating what properties the clients find valuable in an electronic wallet, is a stage in transit towards a cashless society.

Payment cards are more secure and convenient for the consumers. More than 1.2 billion credit cards are now in use around the world, accepted at more than 23 million locations (Solat, 2017). The payments cards are now even more convenient with the wireless computer network which has allowed the POS to go mobile. Payment can now be done at the customers point this has increased customer satisfaction especially in the hotel industry where the technology has already been embraced. E-payment tends to benefit businesses by extending customers base, boosting cash flow, reducing costs, enhancing customer service and improving competitive advantage. E-payment improves customer service by providing choices; it can offer a wide range of payment options which makes it convenient to perform transactions (Akhisar \& Tunay, 2015). The varieties in payment options also bring about competition with competitor trying to offer full range of payment options (Rafique, Rizwan, Batool,\& Aslam, 2014).

Numerous African markets have been building the foundation for 'cashlessness' for quite a while including moderate and comprehensively accessible money related items, a lively and aggressive vendor commercial center, a straightforward and beneficial business condition (Agwu \& Carter, 2014). Likewise, Africa's administrations and Central Banks are looking to enhance money related incorporation and drive in-bound venture, new and energizing open doors are developing for both conventional banks and Financial Technology new companies. In the last decade, innovation in the financial services sector in Africa has seen the 
introduction of internet banking, multi-currency cards and mobile money transactions amongst other things. Africa is on a steady growth path with a more progressive approach in terms of financial services adopting technology (Agwu \& Carter, 2014). In South Africa approximately $30-35 \%$ of retail payments are electronic and $60-65 \%$ are cash payments (Thomas \&Angus, 2013). Nigeria is ranked second in Africa among countries that have significantly adopted e-payments system (Thomas \& Angus, 2013). They further note that $27 \%$ of Nigerians had fully adopted the cashless system for settling bills, buying goods and paying for various services with the number rising sharply due to reliable mobile phone cash transactions. Nigeria's Trajectory reflects a substantial shift in share of consumer payment value from cash to electronic based payment between 2006 and 2011.

Past investigations on the e-payments have acknowledged the role it plays on financial performance of bank-based financial institutions. Mugambi, Njunge and Yang (2014) in their study on the effect of the credit cards on the financial performance of retail firms' portfolio acknowledges the fact that the credit cards have a positive effect on the financial performance of the commercial banks in Nigeria. Kamar (2012) in the study on the effect of the electronic credit card usage on a firm agrees with Odhiambo (2012) that there is a positive effect between the number of the credit cards, the net income from the credit cards and the profitability. Muiru (2014) in his study the effects of financial innovation on financial performance of retailers found out that the firms that had adopted some forms of financial innovation like the credit cards, mobiles and agency banking and these had a great impact on the financial performance of the retailers. According to CBK annual reports (2018), the value of transactions effected through cards in the year to June 2017 increased by 6.4 percent and 79.1 percent from Kshs 673.31 billion to Kshs716.44 billion for acquirers and issuers, respectively. The growing usage of card signifies a growing shift from cash based payments to non-cash based payments (Kosse \& Welte, 2017).

Thomas and Angus (2013) indicate that Nigeria is second to South Africa as the most formalized African country in terms of formal retail penetration with retail penetration standing at around 30 per cent. The retail market is dominated by three major outlets; Tuskys, Uchumi and Naivas (Euromonitor report, 2018). Three of them (except Naivas) have already crossed into the neighbouring countries. Nakumatt is the largest retailer in Nigeria in terms of sales. It has 37 stores, followed by Tuskys which has 37 outlets, Uchumi 18 outlets and then Naivas with 19 branches. Nakumatt is also present in Uganda, Tanzania and Rwanda, while Tuskys and Uchumi are also in Uganda. Use of the formal outlets increases customer choices, while creating employment.

In retrospect, before the evolution of modern banking operations, virtually all the aspects of banking operations were done manually. It was cumbersome, transactions processing, postings and cheque settlement transactions were sluggish and time-consuming. The banks operated ledger system and manual recordings. In this 70's and early 80's of banking operations phases, transactions were shredded in multiple of commission or omission of errors, snail-pace speed and belated (Ovie, 2001). Then, cheque clearing in upcountry took about twenty-one days before value was received while local cheque took about fourteen (14) days for the same manner. The ever increasing emerging markets and its attendant customer sophistication, the passion for speedy, accurate, real time, efficient and swift service delivery has spurred banks into exploring and exploiting the opportunities in dynamic environment with complex exogenous factors. The globalization of trade and commerce unlashed pressure 
effects on banks to retune their operations to key-in the global village of business dealings and to achieve optimal performance (Ashaolu,2004).

The above assertion has led banks to take giant strides into technological developments in the areas of telecommunications and information technology which are significantly impacting on businesses. The electronic banking policy came upstream in 2002 but banks implementation was at low ebb. Central Bank of Nigeria in 2002 and 2003 rolled out guidelines on Automated Clearing System and Alternative Payment Systems in Nigeria. At this phase, DMBs started to adapt and adopt technology upgrading for effective service delivery to the teaming customer needs. In 2004, e-products became imperative for service delivery channels to match with competitive emerging market in the industry. To suffice the policy implementation, in 2012, Cashless Policy and Guidelines on Debit Cards came on board by CBN to regulate the financial institutions. According to Onay et al (2008), the increased adoption and penetration of internet banking has recently redefined the playground of retail banks. Also, the emergence of the global economy, e-business and e-payment have substantially become the necessary components of business strategy and a strong catalyst for economic development, efficient service delivery and effective wide reach out to the customers and clienteles.

The electronic banking revolution basically centers on changes in distribution channels using electronic products. The basis of the emergence of the modern electronic distribution channels is the result of the evolution of the concept of money. In the days of barter, the ability to pay for goods and services was reflected in the physical existence of goods, which could be used for exchange. Then, came hard cash in the form of coins made out of precious metals. This was then followed by the fiduciary money called the modern coin and paper notes. Today, individual's ability to pay for goods and services is simply reflected in accounting records of his or her bank. Thus, it is important to appreciate at the outset as its new definition is just simply information, which can be electronically transmitted to facilitate economic and financial transactions. It is this new definition of money, which has resulted in the electronic revolution of financial institutions (Balachandher, 2001). Many Nigerian banks have streamlined their operations by investing in automation to enhance performance and build competitive advantage as the environmental terrain is becoming more challenging to navigate, which needs technology adoption.

Some empirical analysis shows that electronic payment products have made significant contribution to the financial performance of the DMBs in Nigeria. Milind (2005) revealed in his study the there was no significant impact of internet banking on the financial performance of DMBs. Shuquir (2003) study also revealed negative impact of the e-products on the banks' performance. Trajhora (2005) carried empirical investigation on the impact of e-payment products on banks' performance and found that there was increase in the profitability. Siam (2006) in his study corroborated the study of Trajhora (2005), and also in De-Young et al (2007), Hernando and Neto (2007) found from their empirical results that there were significant impact on the profitability performance of the DMBs in Nigeria, hence contradicting the works of Milind (2005) and Shuquair (2003).

Therefore, it is against this backdrop of evidences and counter evidences about the impact of e-payment products (POS \& ATM) on bank's performance that this study intends to provide obvious evidence of the impact of various e-products on the financial performance of DMBs by employing higher econometric models such as Panel Regression, Cointegration test, Eigenvalue and Condition Index, Durbin Watson, Granger Causality Tests in addition to 
existing literature and expanding the frontier of knowledge. Also, DMBs focused more on profit-making thereby neglecting the adoption of the underpinning theory of Technology Acceptance Model to harness the full benefits of electronic payment products in their service delivery mechanism. The remainder of this empirical paper is organized as follows: Section 2 highlight the review of related literature and hypotheses development level. Section 3 presents the methodology. Section 4 discusses the empirical results, while section 5 presents the concluding remark, recommendation, limitation and suggestion for further studies

\section{Literature Review and Hypothesis Development Level}

\section{Theoretical foundation}

The Technology Acceptance Model theory was postulated by Davis (1989) and states that Perceived Usefulness and Perceived Ease of Use are the main drivers of technology and determine an individual's intention to adopt a technology. This theory supports how cash handling practices influence financial performance. According to Bátiz-Lazo (2018), the intention to use serves as mediator of the actual adoption of technology. According to TAM, the decision to adopt a technology follows the four stages, explained as follows according to Bátiz-Lazo (2018). Stage one is where the external variables such as individual user beliefs or differences with Information Technology. Their evaluation is reflected in Perceived Usefulness (PU) and Perceived Ease of Use (PeU). Whereas perceived usefulness is a user perception that using the new system would increase his/her performance in the organization and perceived ease of use is the extent to which using the new system would require minimal effort on a user's behalf (Tilakaratna, 2016).

Stage two is attitude which is a consequence of the user's beliefs of using a technology drives the user's attitude towards accepting/rejecting the technology. Stage three is intention where the attitude predicts the desirability of the user using the system and the extent of them using it. Stage four is actual use which is the user's intention to determine how well they would actually use the system. The adoption of technology depends on personal behaviour and external environment. People perceive that by using technology, they will obtain more benefits without doing much physical and mental effort (Tilakaratna, 2016).

Davis et al (1989), describe TAM as an information system theory that models how users come to accept and use a technology based system. TAM explains the perceived usefulness and usage intentions in terms of social influence and cognitive instrumental processes. They evaluated Diffusion from phenomenological view as 'technology is information and people should use it to achieve value'. TAM involves two primary predictors for the potential adopter- Perceived Usefulness (PU) and Perceived Ease of Use (PEOU) of technology as the main determinants of the attitudes toward a new Technology. PU is the degree to which a person believes that using a particular system would enhance his or her job performance. PEOU is the degree to which a person believe that using a particular system would be free of effort (Davis, 1989 cited in Fonchamnyo, 2013).

Gefen, Karahanna and Straub (2003) studied a separate and distinct interaction of both the actual e-vendor and with its IT Web site interface is at the heart of online shopping. Previous research has established, accordingly, that online purchase intentions are the product of both consumer assessments of the IT itself-specifically its perceived usefulness and ease-of-use (TAM)-and trust in the e-vendor (Nithin \& Baiju, 2018). The research showed that consumer 
trust is as important to online commerce as the widely accepted TAM use-antecedents, perceived usefulness and perceived ease of use. Thus these variable sets explain a considerable proportion of variance in intended behavior. The study also provided evidence that online trust is built through the belief that the vendor has nothing to gain by cheating, the belief that there are safety mechanisms built into the Web site, and lastly by having a typical interface that is easy to use.

\section{Conceptual Framework}

\section{E-payment}

An e-payment is a way of making transactions or paying for goods and services through an electronic medium, without the use of checks or cash. It's also called an electronic payment system or online payment system. The electronic payment system has grown increasingly over the last decades due to the growing spread of internet-based banking and shopping. As the world advances more with technology development, we can see the rise of electronic payment systems and payment processing devices. As these increase, improve, and provide ever more secure online payment transactions the percentage of check and cash transactions will decrease as explained by Solat (2017).

According to Daniel (1999) and Sathye (1999), they posit e-payment as the newest channel for delivering banking services in the world, and observed that e-payment refers to several types of services through which bank customers can request for information and carry out most retail banking services via computers or mobile phones. Burr (1996) describes epayment as an electronic link between the bank and the customer in order to prepare, manage and control financial transactions.

In Anyanwokoro (1999), electronic banking is defined as the application of computer technology to banking especially the payment (deposit transfer) aspects of banking. He also defined e-payment as a system of banking with an electronic communication network which permits on-line processing of the same day credit and debit transfers of funds between member institutions of a clearing system. Electronic banking offers the convenience of conducting most of the banking transactions at a time that suits the customer. The customer can access funds and transfer funds between accounts, pay bills, make purchases and transfer money with ease at any time.

Hertzum et al (2004), defined e-payment as web-based banking. In other words, E-payment refers to the banking operations, which is done over worldwide web. However, more comprehensive and well established definition is given by the United Nations Conference on Trade and Development (UNCTAD), they describe it as the deployment over the internet of retail and wholesale banking services, which involves individual and corporate clients, and includes banking transfers, payments and settlements, documentary collections and credits, corporate and household lending, card business and some others (UNCTAD, 2002).

Omotayo (2007) defines electronic banking as a system in which funds are moved between different accounts using computerized online or real time systems without the use of written cheque. Kondabagil (2007) noted that "electronic banking is like traditional payment, inquiring and information processing systems, differing only in that it utilizes a different delivery channel. For banks to stay on track of competition there is need to be aware of the rapid and continual growth of information technology and telecommunications which encourage the introduction of electronic services of the banking activities.Also, electronic banking is defined to include the provision of retail and small value banking products and 
services through electronic channels as well as large value electronic payments and other whole sale banking services delivered electronically.

In the works of Alhajri (2008), he described e-payment as the provision of banking services to customers through the use of internet technology. Migdadi (2008), views internet banking as quality service encounter of retail banks in Jordan and its quality dimensions that should be sustained to achieve specific purposes of the bank, that banks in Jordan should focus on providing a better service quality to their customers as a result of the impact of quality service delivery on the customers' retention.

In Aburime (2008) electronic banking includes systems that enable financial institutions, customer, individual and business to access accounts, transact business or obtain information on financial products and services through public or private networks including the internet. Customers access electronic banking services using an intelligent electronic device such as a personal computer (PC), personal digital assistant (PDA), Automated Teller Machine (ATM), among others.

Electronic banking can be viewed as a system by which transactions are settled electronically with use of electronic gadgets such as ATMs, POS terminals, GSM Phones and v-cards etc handled by e-holders, bank customers and stakeholders. Banking over the internet has attracted increasing intention from banks and other financial services industry, from participants, the business press, regulators and law makers, both in Nigeria and other countries.

According to Imiefoh (2012), refers to e-payment as the delivering services more effectively and in so doing, reinforces revenue increase, the goal is to ensure that a customer performs banking transactions electronically without physically visiting the brick-and-mortar institution

Khrawish and AL-Sadi (2012) defined electronic banking as the adoption of electronic means in the delivery of banking products and services. Such products and services include deposit taking, lending and payment products and provision of other electronic payment product and services such as electronic money.

In the researcher's view, the "electronic payment products are those differentiated products or services but similar in modus operandi offered by the deposit money banks to meet the perceived needs and efficient service delivery demands of the customer, in order to contend with the competitive and dynamic banking environment".

Note that electronic banking and electronic products are two siamese twins that move together through technological systems, also from the above definitions, the research defines the electronic banking as the delivery of banking products (intangible services) through the use of ATM, POS, Mobile Pay, Web Pay, SMS-Alert to the customers and banking public electronically to enhance corporate performance objective.

According to Abaenewe et al (2013), e-payment is the conduct of banking business electronically which involves the use of information communication technology to drive banking business for immediate and future goals. Electronic Banking System (EBS) is seen to be an innovative service delivery mode that offers diversified financial services like cash withdrawals, funds transfers, cash deposits, payment of utility, credit card bills, cheque book request, financial enquiries, (Onyedimekwu \& Oruan, 2013).

\section{Return on Equity}


Return on equity (ROE) is a measure of financial performance calculated by dividing net income by shareholders' equity. Because shareholders' equity is equal to a company's assets minus its debt, ROE could be thought of as the return on net assets. Return on equity (ROE) deemed good or bad will depend on what's normal for a stock's peers. For example, utilities will have a lot of assets and debt on the balance sheet compared to a relatively small amount of net income. A normal ROE in the utility sector could be $10 \%$ or less. A technology or retail firm with smaller balance sheet accounts relative to net income may have normal ROE levels of $18 \%$ or more. A good rule of thumb is to target an ROE that is equal to or just above the average for the peer group (Saragih, 2018).

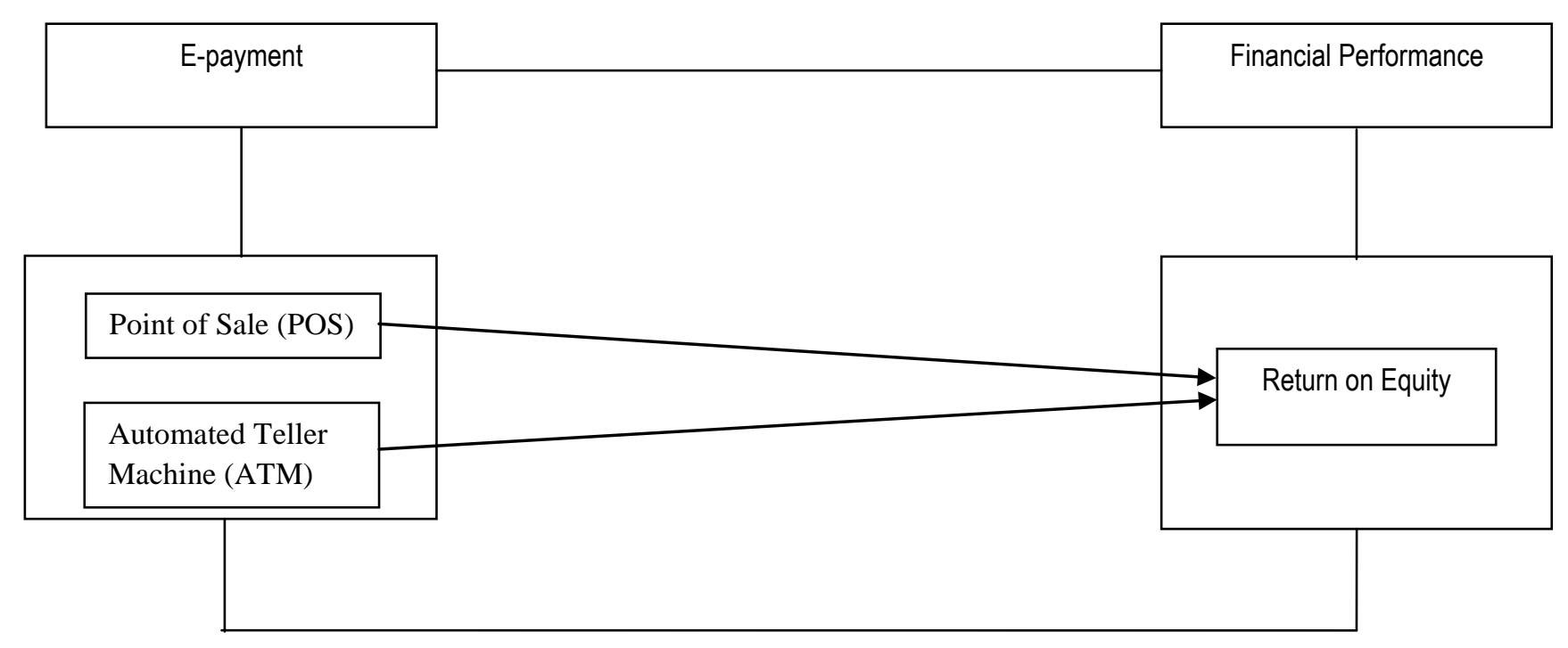

Figure 1: Operational Conceptual Framework of E-payment and Financial Performance of Quoted Deposit Money Bank in Nigeria.

\section{Empirical Results}

Ogutu and Fatoki (2019) examined the effect of electronic banking on financial performance of listed commercial banks in Kenya. This study was guided by four objectives, establishing the effect of mobile banking, agency banking, ATM banking and online banking on financial performance of listed commercial banks in Kenya. The study employed quantitative research design using panel data analysis. The targeted population of the study was the 11 listed commercial banks in Kenya. Secondary data was extracted from CBK banking supervisory reports and published annual reports of banks. The data was recorded on data collection sheets. Both descriptive and inferential statistics were used. The findings were presented using tables with associated explanations. The study found that there was strong positive relationship between mobile banking, agency banking, ATM banking and online banking and financial performance of listed commercial banks in Kenya. Financial performance of commercial banks and m-banking were strongly and positively correlated. There was a strong positive correlation between financials performance of individual commercial and agency banking. There was a weak positive correlation between financial performance of individual commercial bank and online banking.

Chen and Srinivasan (2019) examined the firm value and performance implications of the growing trend of non-technology (non-tech) companies adopting digital technologies such as 
artificial intelligence, big data, cloud computing, machine learning. For the entire universe of US public listed firms, we identify companies that are going digital using textual analysis of disclosure of digital-related words in corporate financial reports and conference calls. We first show that digital adoption by non-tech firms has dramatically grown in recent years. Non-tech digital adopters exhibit greater stock price co-movement with technology companies than with their industry peers, suggesting that the digital activities are making them similar to tech firms. The digital adopters hold more cash and are larger, younger and less CapEx-intensive. Digital adoption is associated with higher valuation - market-to-book ratio is higher by $7-21 \%$ than industry peers - and is higher for firms that are younger, more CapEx-intensive, exhibit higher sales growth and are in industries where digital adoption is prevalent. However, markets are slow to respond to the disclosure of digital activity. Portfolios formed on digital disclosure earn a size/book-to-market adjusted return of $25 \%$ over a 3-year horizon and generate a monthly alpha of 40 basis points. Finally, while there is no significant improvement in financial performance as measured by return-on-assets conditional on digital activities, there is a significant increase in asset turnover but also a significant decline in margins and sales growth. Managerial expertise is important for digital technology adoption, as firms with senior technology executives perform better when going digital.

Xena and Rahali (2019) evaluates the influence of the adoption of e-payment on enterprise performance. Through this study, the researcher gets a new model from author analysis based on 23 previous literature synthesis and find out six independent variables and espouse adoption of e-payment to support small-medium enterprise payment system, that are performance expectancy, culture, acceptance of technology, social influence, security and effort expectancy. The result of this study would be useful to understand about the adoption of e-payment to support the small-medium enterprise payment system.

Ibanichuka and Oko (2019) investigated the relationship between electronic frauds and financial performance of quoted banks on the Nigerian Stock Exchange. Point of sale fraud was electronic fraud proxy while return on investment was the proxy of financial performance. The researchers adopted expost-facto research design for the study. The study used relevant secondary data obtained from Nigerian Electronic Fraud Forum, Nigeria Deposit Insurance Corporation, and Central Bank of Nigeria (CBN) from 2013 to 2017. The relevant secondary data were analyzed using basic descriptive, Pearson Product Moment Correlation and multivariate regression in a panel data setting with econometric analyses like Unit roots, granger causality test and cointegrated test. The results showed negative and insignificant relationship between electronic fraud channels and financial performance variables. The study concluded that there is no significant relationship between the electronic fraud and financial performance of quoted commercial banks in Nigeria in the period of this study.

Chipeta and Muthinja (2018) examine the relationship between financial innovation and the financial performance of 42 commercial banks in Kenya. The financial innovations covered are the branchless banking models, which represent a departure from the traditional branchbased banking. More specifically, the financial innovations covered are: mobile banking, agency banking, internet banking and automated teller machines. we use the Koyck dynamic distributed lag model to estimate the relationship between financial innovations and bank financial performance. The model has been using dynamic panel estimation with system generalized methods of moments. The results show that financial innovations significantly 
Journal DOI: www.doi.org/10.46654/RJMP

Article DOI: www.doi.org/10.46654/RJMP.7325

contribute to bank financial performance, and that firm-specific factors are more important in determining the firm's current financial performance than industry factors.

Table 1: Webometric Analysis of E-payment and Financial performance of Quoted Deposit Money Banks in Nigeria

\begin{tabular}{|c|c|c|}
\hline Author(s) and Year & Research Topic & $\begin{array}{c}\text { Journal, Volume, Numbers and } \\
\text { Pages }\end{array}$ \\
\hline $\begin{array}{l}\text { Abaenewe, Ogbulu \& } \\
\text { Nelugbu (2013) }\end{array}$ & $\begin{array}{l}\text { Electronic banking and bank } \\
\text { performance in Nigeria. }\end{array}$ & $\begin{array}{l}\text { West African Journal of Industrial } \\
\text { and Academic research 16(1), } 171 \\
-187\end{array}$ \\
\hline $\begin{array}{l}\text { Adeniran, \& } \begin{array}{l}\text { Junadia } \\
\text { (2017) }\end{array} \\
\end{array}$ & $\begin{array}{l}\text { An empirical study of Automated } \\
\text { Teller Machine (ATM) and uses } \\
\text { satisfaction in Nigeria: A study of } \\
\text { United Bank for Africa in Sokoto } \\
\text { Metropolis }\end{array}$ & $\begin{array}{lcr}\text { International } & \text { Journal } & \text { of } \\
\text { Management } & \text { Technology, } & 2(3) \text {, } \\
001-0011 & & \end{array}$ \\
\hline $\begin{array}{l}\text { Akhisar TunAy \& Tonay, } \\
\text { (2015) }\end{array}$ & $\begin{array}{l}\text { The effects of innovations on bank } \\
\text { performance: The care of } \\
\text { electronic banking services }\end{array}$ & $\begin{array}{llll}\text { Pvavedia } & - & \text { social } & \text { and } \\
\text { Belewiowial } & \text { sciences, } & 19(5), & 369 \\
-375 & & & \\
\end{array}$ \\
\hline Aranyossy (2018) & $\begin{array}{l}\text { Citizen adoption of E-government } \\
\text { services: Evidence from Hungary }\end{array}$ & $\begin{array}{l}\text { Digital transformation meeting the } \\
\text { challenges } 10(3), 4-3\end{array}$ \\
\hline Balaji \& Balaji (2017) & $\begin{array}{l}\text { A study on demonetization and its } \\
\text { impact on cashless transactions }\end{array}$ & $\begin{array}{l}\text { International Journal of Advanced } \\
\text { Scientific Research \& } \\
\text { Development, } 4(3), 58-64\end{array}$ \\
\hline $\begin{array}{l}\text { Barngetuny \& Kimuton, } \\
\text { (2015) }\end{array}$ & $\begin{array}{l}\text { Effect of e-payment on supply } \\
\text { chain management performance in } \\
\text { Elgeyo-Marakwet Country. }\end{array}$ & $\begin{array}{l}\text { International Journal of Research } \\
\text { in Business Mgt, 3(11), } 43-56\end{array}$ \\
\hline $\begin{array}{l}\text { Akinyomi \& Adebayo, } \\
\text { (2013) }\end{array}$ & $\begin{array}{l}\text { Effect of form size on profitability: } \\
\text { Evidence from Nigerian } \\
\text { manufacturing sector. }\end{array}$ & $\begin{array}{l}\text { Prime Journal of Business } \\
\text { Administration and Mgt (BAM), } \\
3(9), 1171-1175\end{array}$ \\
\hline Alhahri (2008) & $\begin{array}{l}\text { The adoption of e-payment: The } \\
\text { care of Omani Bank. }\end{array}$ & $\begin{array}{l}\text { International review of Business } \\
\text { Research Popes, 4(5), } 120-128\end{array}$ \\
\hline $\begin{array}{l}\text { Asamoah, Takieddine \& } \\
\text { Amedotu (200) }\end{array}$ & 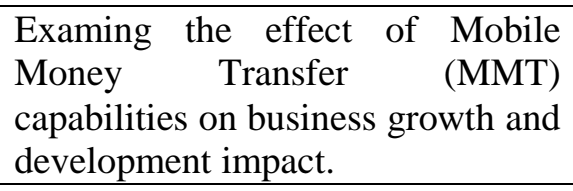 & $\begin{array}{l}\text { Information Technology for } \\
\text { Development, 26(1), 146-161 }\end{array}$ \\
\hline Bilgiham (2016) & $\begin{array}{l}\text { General customer loyalty in online } \\
\text { shopping: An integrated model of } \\
\text { trust user experience and branding }\end{array}$ & $\begin{array}{l}\text { Computers in Human Behaviour, } \\
61(3), 103-113\end{array}$ \\
\hline Daniel (2017) & $\begin{array}{l}\text { Provision of electronic banking in } \\
\text { the UK and the Republic of Ireland }\end{array}$ & $\begin{array}{l}\text { International Journal of } \text { Bank } \\
\text { Marketing 17(2), } 72-82\end{array}$ \\
\hline Deyoung (2017) & $\begin{array}{l}\text { How the internet affects the output } \\
\text { and performance at community } \\
\text { banks }\end{array}$ & $\begin{array}{l}\text { Journal of Banking and Finance, } \\
31(1), 1033-1060\end{array}$ \\
\hline Ekwaeme (2012) & $\begin{array}{l}\text { An empirical assessment of the } \\
\text { operational efficiency of the } \\
\text { electronic banking: Evidence of } \\
\text { Nigerian Banks. }\end{array}$ & $\begin{array}{l}\text { Review of Public Administration } \\
\text { and management, } 1(2), 108-132\end{array}$ \\
\hline Ene \& Itah (2014) & $\begin{array}{l}\text { Impact of cashless banking on } \\
\text { banks profitability: Evidence from } \\
\text { Nigeria }\end{array}$ & $\begin{array}{l}\text { Asian Journal of Finance and } \\
\text { Account, } 6(1), 362-376\end{array}$ \\
\hline Enoruwa, & Electronic channels and bank & International \\
\hline
\end{tabular}


Journal DOI: www.doi.org/10.46654/RJMP

Article DOI: www.doi.org/10.46654/RJMP.7325

\begin{tabular}{|c|c|c|}
\hline Nwani (2019) & $\begin{array}{lll}\text { performance: } & \text { Evidence } & \text { from } \\
\text { Nigeria } & & \\
\end{array}$ & $\begin{array}{l}\text { Economics and Management } \\
\text { Studies 6(5), } 37-46\end{array}$ \\
\hline $\begin{array}{l}\text { Adeoti \& } \quad \text { Osotimehin } \\
(2012)\end{array}$ & $\begin{array}{l}\text { Adoption of sale terminals in } \\
\text { Nigeria: Assessment of consumers } \\
\text { level of satisfaction. }\end{array}$ & $\begin{array}{l}\text { Research Journal of Finance and } \\
\text { Accounting, 3(1), } 1-5\end{array}$ \\
\hline $\begin{array}{l}\text { Alawiye-Adams } \\
\text { Afolabi (2013) }\end{array}$ & $\begin{array}{l}\text { Analyzing the impact of electronic } \\
\text { banking on the payment systems } \\
\text { and the success factors. }\end{array}$ & 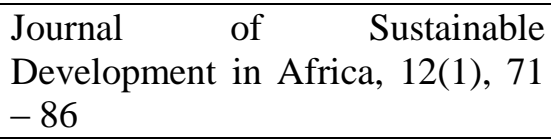 \\
\hline $\begin{array}{l}\text { Alinejadi Arhab } \quad \& \\
\text { Mehrabi (2013) }\end{array}$ & $\begin{array}{l}\text { The effect of the New Electronic } \\
\text { Payment Instruments in the } \\
\text { Liquidity of Banks. }\end{array}$ & $\begin{array}{l}\text { Technical Journal of Engineering } \\
\text { and Applied Sciences, 3(1), } 3747 \\
-3751 \text {. }\end{array}$ \\
\hline $\begin{array}{l}\text { Antwi, Hamza, Bavoh, } \\
\text { (2015) }\end{array}$ & $\begin{array}{l}\text { Examining the effectiveness of } \\
\text { electronic payment system in } \\
\text { Ghana: The case e-zwich in the } \\
\text { tamele metropolis }\end{array}$ & $\begin{array}{l}\text { Research Journal of Finance and } \\
\text { Accounting, } 6(2), 163-177\end{array}$ \\
\hline Bupat (2012) & $\begin{array}{ll}\text { Customer relationship } & \text { for } \\
\text { electronic payment products: An } & \text { An } \\
\text { empirical investigation in India. }\end{array}$ & $\begin{array}{l}\text { Global Business Review, 13(1), } \\
137-151\end{array}$ \\
\hline $\begin{array}{l}\text { Teoh, Chong, Lin \& } \\
\text { Chuce (2013) }\end{array}$ & $\begin{array}{l}\text { Factors affecting consumers' } \\
\text { perception of electronic payement: } \\
\text { An empirical analysis. }\end{array}$ & $\begin{array}{l}\text { Internet Research, 23(4), } 465- \\
485\end{array}$ \\
\hline Jani (2015) & $\begin{array}{l}\text { The influences of trust and security } \\
\text { in the use of electronic payment } \\
\text { system in Monado. }\end{array}$ & $\begin{array}{l}\text { Journal Riset Ekonomi, Mana, } \\
\text { Emem, Business and Akuntani, } \\
3(1), 32-41\end{array}$ \\
\hline Dlozko, Epele, (2015) & $\begin{array}{l}\text { Problems and rules of digital } \\
\text { technologies introduction into e- } \\
\text { payments. }\end{array}$ & $\begin{array}{l}\text { Transformations in Business and } \\
\text { Economics, 14(1), 42-59. }\end{array}$ \\
\hline Roy \& Sinha (2014) & $\begin{array}{l}\text { Determinants of customers' } \\
\text { acceptance of electronic payment } \\
\text { system in Indian banking sector, A } \\
\text { study. }\end{array}$ & $\begin{array}{l}\text { International Journal of Scientific } \\
\text { and Engineering Research, 5(1), } \\
177-187\end{array}$ \\
\hline $\begin{array}{l}\text { Premchand \& Chondlry } \\
\text { (2015) }\end{array}$ & Future of payments - epayment. & $\begin{array}{l}\text { International Journal of Emerging } \\
\text { Technology and Advanced } \\
\text { Engineering 5(2), 110-115 }\end{array}$ \\
\hline $\begin{array}{l}\text { Ozkan, Bindusowa, } \\
\text { Aackney (2010) }\end{array}$ & $\begin{array}{l}\text { Facilitating the adoption of e- } \\
\text { payment systems: theoretical } \\
\text { constraints and empirical analysis }\end{array}$ & $\begin{array}{l}\text { Journal of enterprise information } \\
\text { management, } 23(3), 305-325\end{array}$ \\
\hline Lin, Nguen (2011) & $\begin{array}{l}\text { Exploring e-payment adoption in } \\
\text { Vietnam and Taiwan. }\end{array}$ & $\begin{array}{l}\text { Journal of Computer Information } \\
\text { System, } 51(4), 31-49\end{array}$ \\
\hline Kaur \& Pathak (2015) & $\begin{array}{l}\text { E-payment system on E-commerce } \\
\text { in India. }\end{array}$ & $\begin{array}{l}\text { Karamjeet Kaur International } \\
\text { Journal of Engineering Research } \\
\text { and Applications, 5(2), 79-87 }\end{array}$ \\
\hline Ngeseza \& Iravo (2013) & 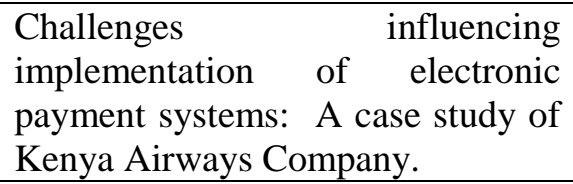 & $\begin{array}{l}\text { International Journal of Social } \\
\text { Sciences and Entrepreneurship, } \\
1(3), 509-520\end{array}$ \\
\hline Odi \& Richard (2013) & $\begin{array}{l}\text { Electronic payment in cashless } \\
\text { economy of Nigeria: Problems and } \\
\text { prospects }\end{array}$ & $\begin{array}{l}\text { Journal of Management Research, } \\
5(1), 138-151\end{array}$ \\
\hline Nzoro (2014) & $\begin{array}{l}\text { Assessing the role of electronic } \\
\text { payment systems in Financial } \\
\text { Institutions: A case of a savings }\end{array}$ & $\begin{array}{l}\text { Global Journal of Management } \\
\text { and Business Research, 14(2) }\end{array}$ \\
\hline
\end{tabular}


Journal DOI: www.doi.org/10.46654/RJMP

Article DOI: www.doi.org/10.46654/RJMP.7325

\begin{tabular}{|c|c|c|}
\hline & bank in Zimbabwe. & \\
\hline Nwaolisa \& Kasie (2011) & $\begin{array}{l}\text { Electronic retail payment systems: } \\
\text { User acceptability and payments } \\
\text { problems in Nigeria. }\end{array}$ & $\begin{array}{l}\text { Arabian Journal of Business and } \\
\text { Management Review (OM AW. } \\
\text { Chapter), 1(5), 66-76 }\end{array}$ \\
\hline $\begin{array}{l}\text { Muhayiddian, Ahmed \& } \\
\text { Ismail(2011) }\end{array}$ & $\begin{array}{l}\text { Technology acceptance of a gold } \\
\text { dinar based electronic payment } \\
\text { system. }\end{array}$ & $\begin{array}{l}\text { Research in Business, 3(3), } 295- \\
310\end{array}$ \\
\hline $\begin{array}{l}\text { Aussein, Mohamed, Ahlan } \\
\& \text { Mohamed, (2010) }\end{array}$ & $\begin{array}{l}\text { E-govt. application: An integrated } \\
\text { model on G2C adoption of online } \\
\text { tax. }\end{array}$ & 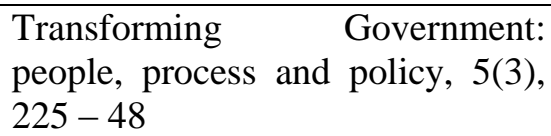 \\
\hline $\begin{array}{l}\text { Ogedebe \& Babatunde, } \\
\text { (2012) }\end{array}$ & 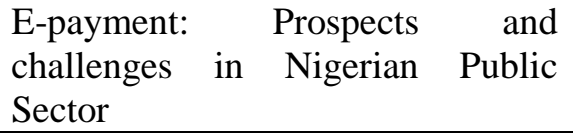 & $\begin{array}{l}\text { International Journal of Modern } \\
\text { Engineering Research (IJMER) } \\
2(5), 3104-3106\end{array}$ \\
\hline $\begin{array}{l}\text { Humphrey, Kim \& Vale, } \\
\text { (2001) }\end{array}$ & $\begin{array}{l}\text { Realizing the gains from electronic } \\
\text { payments; cost, pricing choice. }\end{array}$ & $\begin{array}{l}\text { Journal of money, credit and } \\
\text { banking, 33(23), 216-234 }\end{array}$ \\
\hline Ayo (2011) & $\begin{array}{l}\text { Emergence of payment systems in } \\
\text { the era of e-commerce in Nigeria: } \\
\text { problems and prospects. }\end{array}$ & $\begin{array}{l}\text { Belta Business Education Journal, } \\
1(6), 64-72\end{array}$ \\
\hline $\begin{array}{l}\text { Asaolu, Ayoola } \quad \& \\
\text { Akinkoye (2011) }\end{array}$ & $\begin{array}{l}\text { Electronic payment system in } \\
\text { Nigeria, constraints and solution. }\end{array}$ & $\begin{array}{l}\text { Journal of Management and } \\
\text { Society, 1(2), 16-21 }\end{array}$ \\
\hline
\end{tabular}

\section{Hypotheses Development Level}

These two hypotheses, formulated in the null form, also serve as robustness checks among variables of the study.

$\mathrm{H}_{01}$ : There is no significant relationship between point of sale and return on equity of quoted deposit money banks performance in Nigeria.

$\mathrm{H}_{02}$ : Automated Teller machine (ATM) does not relate to return on equity of quoted deposit money banks performance in Nigeria.

\section{Methodological Foundation}

This section indicates the methodological foundation adopted to explore the relationship between e-payment and performance of quoted Deposit Money Banks in Nigeria. This study utilizes a cross sectional research design which is a combination of both cross-sectional and time-series design properties. Panel analysis permits the study of dynamics of change with short time series. We employed the simple random sampling technique and selected 16 banks due to lack of uniformity in inception of many e-payment in some of the excluded banks and the mergers and acquisition exercise in the others, the study only captures these activities for the period of $2007-2018$.

Panel data regarding the variables of the study were source from Central Bank of Nigeria statistical bulletin, annual Central bank of Nigeria reports, Federal Inland Revenue Service, annual reports and e-business units report of the quoted Deposit Money Banks. We utilized the ordinary Least Square (OLS) of multivariate regression based on Auto-Regressive Distributed Lag (ARDL), unit root test, panel co-integration, Grangers causality and panel dynamic error correction model (Banes jee et al 1993; Granges 1987; Abdullahi et al, 2012; Awe, 2012) with the aid of e-view version 10. 


\section{Model Specification}

The model specification is based on the theory that e-payment contribute to financial performance. Specifically, the model from related empirical studies was adopted. The model specification was formulated in the following functional form as thus:

$\mathrm{ROE}_{\mathrm{t}}=f\left(\mathrm{POS}_{\mathrm{t}}, \mathrm{ATM}_{\mathrm{t}}\right)$

Expanding the functional form into mathematical model as thus:

$\mathrm{ROE}_{\mathrm{t}}=\beta \mathrm{o}_{\mathrm{t}}+\beta_{1} \mathrm{POS}_{\mathrm{t}}+\beta_{2} \mathrm{ATMt}$

Introducing error term into mathematical model to arrive at econometric model as thus;

$\mathrm{ROE}_{\mathrm{t}}=\lambda o_{t}+\lambda_{1} \mathrm{POS}_{\mathrm{t}}+\lambda_{2} \mathrm{ATM}_{\mathrm{t}}+u_{\mathrm{t}}$

Where: ROEt $=$ Return on Equity for the index of time periods

$\mathrm{POS}_{\mathrm{t}}=$ Point of Sale for the index of time periods

$\mathrm{ATM}_{\mathrm{t}}=$ Automated Teller Machine for the index of time periods

$\lambda_{\mathrm{o}}=$ Intercept

$\lambda_{1}-\lambda_{2}=$ Regression shaped for the index of time records

$\mathrm{t}=$ The index of time periods

$u_{\mathrm{t}}=$ Error term for the index of time periods

Empirical Results and Discussion

Table 2: Descriptive Statistics

\begin{tabular}{|l|c|c|c|}
\hline & POS & ATM & ROE \\
\hline Mean & 41.52604 & 59.65104 & 0.119786 \\
\hline Median & 43.00000 & 50.00000 & 0.063500 \\
\hline Maximum & 80.00000 & 80.00000 & 2.360000 \\
\hline Minimum & 0.000000 & 5.000000 & -0.050000 \\
\hline Std. Dev. & 18.67466 & 17.36332 & 0.226252 \\
\hline Skewness & -0.252635 & -0.509276 & 6.585106 \\
\hline Kurtosis & 2.636948 & 2.850447 & 57.25791 \\
\hline Jarque-Bera & 3.096838 & 8.478507 & 2.493900 \\
\hline Probability & 0.212584 & 0.014418 & 0.495721 \\
\hline Sum & 7973.000 & 9533.000 & 22.99900 \\
\hline Sum Sq. Dev. & 66609.87 & 57583.62 & 9.777278 \\
\hline Observations & 192 & 192 & 192 \\
\hline
\end{tabular}


The study observes on the average that ATM is the most patronized electronic payment outlet among sampled dimensions of outlets. The POS channel is the least patronized channel based on its mean value of 41.53. All Payment outlets show negative skewness. A negatively skewed data set has its tail extended towards the left. It is an indication that both the mean and the median are less than the mode of the data set. The most volatile outlet based on standard deviation is he POS channel based on its standard deviation score of 18.67, and POS (18.67). While ATM shows the least volatility based on its relatively low standard deviation value of 17.35 due to consistent growth in usage overtime. This implies that POS is riskiest e-product and could makes negative or unpredictable contribution to the financial performance of the listed DMBs in Nigeria, while on the contrary, ATM generates highest contribution to the financial performance of the DMBs in Nigeria with least standard deviation.

Jarque-Bera Test: Calculates kurtosis and skewness of the asymptotic data. Their values suggest that data obtained for all variables are normal. This implies the normality of the data and substantiates the validity of the regression results.

\section{Stationarity Test/Unit Root Test (ADF - Fisher Chi-square and ADF - Choi Z-statistics).}

To evaluate stationarity tendencies of employed variables, the following unit root test is carried out as presented below.

Table 3 : Unit Root Test at level (0) Output of Return on equity (ROE), Point of Sale (POS) Expenditure (POS), and Automated Teller Machine (ATM) in 16 sample Deposit money banks over the period of 2007 to 2018.

\begin{tabular}{|l|c|c|c|c|c|c|c|}
\hline Variables & $\begin{array}{c}\text { ADF - Fisher } \\
\text { Chi-square }\end{array}$ & Prob & $\begin{array}{c}\text { ADF - } \\
\text { Choi Z- } \\
\text { stat }\end{array}$ & Prob & Note & Discovery & $\begin{array}{c}\text { Conclusion/ } \\
\text { Decision }\end{array}$ \\
\hline ROE $_{\text {it }}$ & 42.9900 & 0.0587 & -1.28344 & 0.2638 & $0(0)$ & $\begin{array}{c}\text { Evidence of Unit } \\
\text { root }\end{array}$ & Not stationary \\
\hline $\mathbf{P O S}_{\text {it }}$ & 41.5119 & 0.0787 & 1.25694 & 0.8956 & $0(0)$ & $\begin{array}{c}\text { Evidence of Unit } \\
\text { root }\end{array}$ & Not stationary \\
\hline $\mathbf{A T M}_{\text {it }}$ & 44.5401 & 0.0426 & 0.33260 & 0.6303 & $0(0)$ & $\begin{array}{c}\text { Evidence of Unit } \\
\text { root }\end{array}$ & Not stationary \\
\hline
\end{tabular}

The above table 3 which shows the stationarity tendencies at level for the selected quoted banks shows that all employed panel series variables show evidence of a unit root as their respective probability levels are higher than the $1 \%, 5 \%$ and $10 \%$ significance level. This shows no form of stationarity in the respective trend at level. This goes to show that, employed variables have high variations in their inherent mean, variance and autocorrelation. This means that variables are not quite stable to show predictive tendencies which is quite bad for analysis and as such will warrant the evaluation of stationarity at first difference which would be present subsequently. 
Table 4: Unit Root Test at First Difference (1) Output of Return on equity (ROE), Point of Sale (POS) Expenditure (POS), and Automated Teller Machine (ATM) in 16 sample Deposit money banks over the period of 2007 to 2018.

\begin{tabular}{|l|l|l|l|l|l|l|l|}
\hline Variables & $\begin{array}{l}\text { ADF - Fisher } \\
\text { Chi-square }\end{array}$ & Prob & $\begin{array}{l}\text { ADF - } \\
\text { Choi Z- } \\
\text { stat }\end{array}$ & Prob & Note & Discovery & $\begin{array}{l}\text { Conclusion/ } \\
\text { Decision }\end{array}$ \\
\hline ROE $_{\text {it }}$ & 100.616 & 0.0000 & -5.89593 & 0.0000 & I(1) & No Unit root & $\begin{array}{l}\text { Stationary at } 1 \mathrm{st} \\
\text { Diff }\end{array}$ \\
\hline POS $_{\text {it }}$ & 75.8911 & 0.0000 & -4.16833 & 0.0000 & I(1) & No Unit root & $\begin{array}{l}\text { Stationary at } 1 \text { st } \\
\text { Diff }\end{array}$ \\
\hline ATM $_{\text {it }}$ & 71.7810 & 0.0000 & -3.11747 & 0.0000 & I(1) & No Unit root & $\begin{array}{l}\text { Stationary at } 1 \mathrm{st} \\
\text { Diff }\end{array}$ \\
\hline
\end{tabular}

Table 4 above shows the employed panel variable at first difference. It can be seen that all probability level are seen to be lower than the $1 \%, 5 \%$ and $10 \%$ significance level. This shows an absence of unit root and presence of stationarity tendencies amongst employed variable. It can be inferred from this that employed variables the variables probability distribution does not change overtime when shifted. This gives room for variables with predictive tendencies and gives rise to further tests like the co-integration test which would be carried out after determining the type of model to utilize (where pooled, random or fixed).

\section{Panel Regressions (Ordinary Least Square)}

The multiple regression was carried out using the Ordinary Least Square regression tool, as it is the best unbiased linear regression estimator, it was carried out in the differenced form.

\section{Pooled Effects regression}

To evaluate for joint influence of employed variables on the criterion, the table above which represents the pooled effect shows that;

Table 5: Pooled Effects Regression Output.

Dependent Variable: $\mathrm{D}(\mathrm{ROE})$

Method: Panel Least Squares

Date: 12/06/19 Time: 00:32

Sample: 20072018

Periods included: 12

Cross-sections included: 16

Total panel (balanced) observations: 192

\begin{tabular}{lrlrr}
\hline \hline \multicolumn{1}{c}{ Variable } & Coefficient & Std. Error & t-Statistic & Prob. \\
\hline \hline C & 9002912. & 4342048. & 2.073425 & 0.0407 \\
D(POS) & -0.156028 & 0.226288 & -0.689511 & 0.4921 \\
D(ATM) & 3.597355 & 4.493480 & 0.800572 & 0.4253 \\
\hline \hline R-squared & 0.452563 & Mean dependent var & 12021453 \\
Adjusted R-squared & 0.418666 & S.D. dependent var & 27231462 \\
S.E. of regression & 25564733 & Akaike info criterion & 36.99777 \\
Sum squared resid & $6.54 \mathrm{E}+16$ & Schwarz criterion & 37.12415 \\
Log likelihood & -1937.383 & Hannan-Quinn criter. & 37.04898 \\
F-statistic & 4.500728 & Durbin-Watson stat & 0.579880 \\
Prob(F-statistic) & 0.002194 & & & \\
\hline \hline
\end{tabular}


Based on the above output in Table 5, it can be easily deduced that Point of Sale (POS) were against the apriori as they both possessed negative coefficient of -0.156028 respectively. Although, only Automated Teller Machine (ATM) showed signifying influence on profitability of firms. This goes to showed that, unilaterally, firms' expenditure of supportive infrastructure, processes and databases of the organization promotes its ability to increase their profitability. The fundamental problem of this model lies from the fact that employed predictor variables jointly account for 45.26 percent of variations in the criterion variables. The second problem with this regression type (pooled effect) is the fact that, it fails to evaluate individuality or heterogeneous tendencies that exist in each of our employed companies. Since all companies cannot be the same, we do not accept this result.

The fixed effect model shows a higher predictive ability over the pooled effect. This is seen from the light of the fact that employed predictor variables account for up to 88.64 percent of variation in the dependent variable (ROE). And the f-statistics of 4.400728 at a probability of 0.002194 which is less than the 0.05(5\%) significance level. While the Durbin Watson is seen to be within the relevant range.

\section{Fixed Effect Regressions}

To deal with the issues of heterogeneity bias, the fixed effect is carried out as follows:

Table 6: Fixed Effects Regression Output.

Dependent Variable: D(ROE)

Method: Panel Least Squares

Date: 12/06/19 Time: 00:55

Sample: 20072018

Periods included: 12

Cross-sections included: 16

Total panel (balanced) observations: 192

\begin{tabular}{|c|c|c|c|c|}
\hline Variable & Coefficient & Std. Error & t-Statistic & Prob. \\
\hline C & 36319009 & 5248544. & 6.919826 & 0.0000 \\
\hline $\mathrm{D}(\mathrm{POS})$ & 1.193380 & 0.153494 & 7.774764 & 0.0000 \\
\hline $\mathrm{D}(\mathrm{ATM})$ & -6.671449 & 2.237966 & -2.981032 & 0.0037 \\
\hline \multicolumn{5}{|c|}{ Effects Specification } \\
\hline \multicolumn{5}{|c|}{ Cross-section fixed (dummy variables) } \\
\hline R-squared & 0.886369 & \multicolumn{2}{|c|}{ Mean dependent var } & 12021453 \\
\hline Adjusted R-squared & 0.862586 & \multicolumn{2}{|c|}{ S.D. dependent var } & 27231462 \\
\hline S.E. of regression & 10094552 & \multicolumn{2}{|c|}{ Akaike info criterion } & 35.25518 \\
\hline Sum squared resid & $8.76 \mathrm{E}+15$ & \multicolumn{2}{|c|}{ Schwarz criterion } & 35.73542 \\
\hline Log likelihood & -1831.897 & \multirow{2}{*}{\multicolumn{2}{|c|}{$\begin{array}{l}\text { Hannan-Quinn criter. } \\
\text { Durbin-Watson stat }\end{array}$}} & 35.44978 \\
\hline F-statistic & 37.26861 & & & 1.814343 \\
\hline Prob(F-statistic) & 0.000000 & \multicolumn{2}{|c|}{ Durbin-Watson stat } & \\
\hline
\end{tabular}

The coefficient significance level shows that all forms of E-payment expenditure by firms have significant tendencies to stimulate profitability of employed firms as they Possess probability level way below the 5\% significance level. Although, Point of Sale (POS) in the form of supportive infrastructure and Automated Teller Machine (ATM) in the form of 
customers vendors and other important constituencies can be seen based on their negative coefficient to drain probability and defy apriori expectations. Despite the dominance of this model (Fixed effect or LSDV model) which allows for heterogeneous factors and individuality amongst employed variables except for the intercept/constant not varying overtime. We further proceed to the Random effect to check for the common mean value of employed variables and their influence on the criterion variable.

\section{Random Effects Model}

Table 7: Random Effects Regression Output.

Dependent Variable: $\mathrm{D}(\mathrm{ROE})$

Method: Panel EGLS (Cross-section random effects)

Date: 12/06/19 Time: 00:55

Sample: 20072018

Periods included: 12

Cross-sections included: 16

Total panel (balanced) observations: 192

Swamy and Arora estimator of component variances

\begin{tabular}{|c|c|c|c|c|}
\hline Variable & Coefficient & Std. Error & t-Statistic & Prob. \\
\hline C & 12910484 & 6149396. & 2.099472 & 0.0383 \\
\hline $\mathrm{D}(\mathrm{POS})$ & 0.975722 & 0.147263 & 6.625710 & 0.0000 \\
\hline $\mathrm{D}(\mathrm{ATM})$ & 0.365332 & 1.944670 & 0.187863 & 0.8514 \\
\hline \multicolumn{5}{|c|}{ Effects Specification } \\
\hline & & & S.D. & Rho \\
\hline Cross-section random & & & 19309520 & 0.7854 \\
\hline Idiosyncratic random & & & 10094552 & 0.2146 \\
\hline \multicolumn{5}{|c|}{ Weighted Statistics } \\
\hline R-squared & 0.291183 & \multirow{5}{*}{\multicolumn{2}{|c|}{$\begin{array}{l}\text { Mean dependent var } \\
\text { S.D. dependent var } \\
\text { Sum squared resid } \\
\text { Durbin-Watson stat }\end{array}$}} & 2330274 . \\
\hline Adjusted R-squared & 0.262831 & & & 14832776 \\
\hline S.E. of regression & 12735209 & & & $1.62 E+16$ \\
\hline F-statistic & 10.27005 & & & 1.052149 \\
\hline \multirow[t]{2}{*}{ Prob(F-statistic) } & 0.000001 & & & \\
\hline & \multicolumn{3}{|c|}{ Unweighted Statistics } & \\
\hline R-squared & -0.732719 & \multirow{2}{*}{\multicolumn{2}{|c|}{ Mean dependent var }} & 12021453 \\
\hline Sum squared resid & $1.34 \mathrm{E}+17$ & & & 0.127699 \\
\hline
\end{tabular}

The random effect above shows a lower predictive ability of employed predictor variables. This is evident as the R-square of 0.291183 shows that employed predictor variables jointly account for only 29.12 percent of variation in Return on equity of financial institutions (ROE). The idiosyncratic random Rho shows 0.2146 which is very low and as such shows a disconnect between employed variables and also their inherent residuals. In this effect, Point on Sale (POS) and Automated Teller Machine (ATM) are seen to go against apriori based on their negative coefficients. Although, only Point of Sale (POS) expenditure (POS) and Automated Teller Machine (ATM) are significant stimulus to profitability. While the former 
promotes it, the latter is seen to adversely affect the financial performance of sampled financial institutions.

\section{Diagnostic test}

The need therefore arises to determine which of the model is most efficient i.e. whether the pooled, random or fixed effect.

\section{Likelihood Ratio Test}

To compare the pooled regression model with the fixed effects model. The null hypothesis favors the pooled model i.e. Unobserved sectional differences are not significant.

\section{Table 8: Likelihood ratio test output.}

Redundant Fixed Effects Tests

Equation: Untitled

Test cross-section fixed effects

\begin{tabular}{lrrr}
\hline \hline Effects Test & Statistic & d.f. & Prob. \\
\hline \hline Cross-section F & 39.669263 & $(14,86)$ & 0.0000 \\
Cross-section Chi-square & 210.972165 & 14 & 0.0000 \\
\hline \hline
\end{tabular}

Cross-section fixed effects test equation:

Dependent Variable: D(ROE)

Method: Panel Least Squares

Date: 12/06/19 Time: 00:57

Sample: 20072018

Periods included: 12

Cross-sections included: 16

Total panel (balanced) observations: 192

\begin{tabular}{lrlrr}
\hline \hline \multicolumn{1}{c}{ Variable } & Coefficient & \multicolumn{1}{c}{ Std. Error } & t-Statistic & Prob. \\
\hline C & 9002912. & 4342048. & 2.073425 & 0.0407 \\
D(POS) & -0.156028 & 0.226288 & -0.689511 & 0.4921 \\
\multicolumn{1}{c}{ D(ATM) } & 3.597355 & 4.493480 & 0.800572 & 0.4253 \\
\hline \hline R-squared & 0.152563 & Mean dependent var & 12021453 \\
Adjusted R-squared & 0.118666 & S.D. dependent var & 27231462 \\
S.E. of regression & 25564733 & Akaike info criterion & 36.99777 \\
Sum squared resid & $6.54 \mathrm{E}+16$ & Schwarz criterion & 37.12415 \\
Log likelihood & -1937.383 & Hannan-Quinn criter. & 37.04898 \\
F-statistic & 4.500728 & Durbin-Watson stat & 0.579880 \\
Prob(F-statistic) & 0.002194 & & \\
\hline \hline
\end{tabular}

The above likelihood ratio test which shows the predominance between the pooled and fixed effect is seen to show a cross-section F-statistics of 39.669263 at a probability level of 0.0000 which is seen to be below the 0.05 significance level. This leads to the rejection of the null hypothesis (the null hypothesis supports the pooled model). The alternate hypothesis which is accepted favors the fixed effect. The study therefore upholds the fixed effect over the pooled 
effect. We therefore proceed to evaluate the better model between the fixed and random model.

\section{Hausman Specification Test}

To compare the random effect model with the fixed test model. The null hypothesis favours the random effects model i.e. $z_{\mathrm{i}}$ are uncorrelated with the explanatory variables (Its null hypothesis is that the random effects model is appropriate while the alternative hypothesis is the fixed effects model is appropriate).

Table 9: Hausman Specification Test output.

Correlated Random Effects - Hausman Test

Equation: Untitled

Test cross-section random effects

\begin{tabular}{lrrr}
\hline \hline Test Summary & $\begin{array}{c}\text { Chi-Sq. } \\
\text { Statistic }\end{array}$ & Chi-Sq. d.f. & Prob. \\
\hline \hline Cross-section random & 62.161515 & 4 & 0.0000 \\
\hline \hline
\end{tabular}

Cross-section random effects test comparisons:

\begin{tabular}{crrrr} 
Variable & Fixed & Random & Var(Diff.) & Prob. \\
\hline \hline D(POS) & 1.193380 & 0.975722 & 0.001874 & 0.0000 \\
D(ATM) & -6.671449 & 0.365332 & 1.226751 & 0.0000 \\
\hline \hline
\end{tabular}

Cross-section random effects test equation:

Dependent Variable: D(ROE)

Method: Panel Least Squares

Date: 12/06/19 Time: 00:58

Sample: 20072018

Periods included: 12

Cross-sections included: 16

Total panel (balanced) observations: 192

\begin{tabular}{|c|c|c|c|c|}
\hline Variable & Coefficient & Std. Error & t-Statistic & Prob. \\
\hline C & 36319009 & 5248544. & 6.919826 & 0.0000 \\
\hline $\mathrm{D}(\mathrm{POS})$ & 1.193380 & 0.153494 & 7.774764 & 0.0000 \\
\hline $\mathrm{D}(\mathrm{ATM})$ & -6.671449 & 2.237966 & -2.981032 & 0.0037 \\
\hline \multicolumn{5}{|c|}{ Effects Specification } \\
\hline \multicolumn{5}{|c|}{ Cross-section fixed (dummy variables) } \\
\hline R-squared & 0.886369 & \multicolumn{2}{|c|}{ Mean dependent var } & 12021453 \\
\hline Adjusted R-squared & 0.862586 & \multicolumn{2}{|c|}{ S.D. dependent var } & 27231462 \\
\hline S.E. of regression & 10094552 & \multicolumn{2}{|c|}{ Akaike info criterion } & 35.25518 \\
\hline Sum squared resid & $8.76 \mathrm{E}+15$ & \multicolumn{2}{|c|}{ Schwarz criterion } & 35.73542 \\
\hline Log likelihood & -1831.897 & \multicolumn{2}{|c|}{ Hannan-Quinn criter. } & 35.44978 \\
\hline F-statistic & 37.26861 & \multicolumn{2}{|c|}{ Durbin-Watson stat } & 1.814343 \\
\hline Prob(F-statistic) & 0.000000 & & & \\
\hline
\end{tabular}


The Hausman specification test output via its cross section random chi square statistics of 62.161515 at a probability level of 0.0000 leads to the rejection of the null hypothesis (the null hypothesis supports the random effect). The alternate hypothesis thus upholds the effect of the fixed model. Therefore, the validity of empirical output of the fixed model stands and is binding on employed variables in the short run.

\section{Lagrange Multiplier Test}

To decide between the random effect and a simple OLS regression, we carry out the Lagrange multiplier test below;

\section{Table 10: Lagrange Multiplier Tests output.}

\begin{tabular}{|c|c|c|c|}
\hline & & est Hypothes & \\
\hline & Cross-section & Time & Both \\
\hline Breusch-Pagan & $\begin{array}{l}75.37672 \\
(0.0000)\end{array}$ & $\begin{array}{l}0.414080 \\
(0.5199)\end{array}$ & $\begin{array}{l}75.79080 \\
(0.0000)\end{array}$ \\
\hline Honda & $\begin{array}{l}8.681977 \\
(0.0000)\end{array}$ & $\begin{array}{c}-0.643490 \\
--\end{array}$ & $\begin{array}{l}5.684068 \\
(0.0000)\end{array}$ \\
\hline King-Wu & $\begin{array}{l}8.681977 \\
(0.0000)\end{array}$ & $\begin{array}{c}-0.643490 \\
--\end{array}$ & $\begin{array}{l}4.216932 \\
(0.0000)\end{array}$ \\
\hline Standardized Honda & $\begin{array}{l}10.15698 \\
(0.0000)\end{array}$ & $\begin{array}{c}-0.438603 \\
--\end{array}$ & $\begin{array}{l}3.130722 \\
(0.0009)\end{array}$ \\
\hline Standardized King-Wu & $\begin{array}{l}10.15698 \\
(0.0000)\end{array}$ & $\begin{array}{c}-0.438603 \\
--\end{array}$ & $\begin{array}{l}1.637342 \\
(0.0508)\end{array}$ \\
\hline Gourierioux, et al.* & -- & -- & $\begin{array}{c}75.37672 \\
(<0.01)\end{array}$ \\
\hline
\end{tabular}

\begin{tabular}{rr} 
*Mixed chi-square asymptotic critical values: \\
$1 \%$ & 7.289 \\
$5 \%$ & 4.321 \\
$10 \%$ & 2.952 \\
\hline \hline
\end{tabular}

The above probability levels at all Lagrange types show probability level less than 0.05 , we therefore reject the null hypothesis. And conclude that random effect is more superior (which supports our even more superior fixed effect). This is evidence of significant differences across firms. Based on this finings, our fixed effect still stands supreme. This shows in the selected model that;

- Assumptions 8 of classical linear regression model (CLRM) is not violated. 
- The regressors included in the regression model are properly estimated.

- The regression coefficients of explanatory variables are determinate and their standard errors are finite.

\section{Panel Co-integration Test}

To evaluate for traces and entrails of long run relationship, the Kao residual co-integration test is carried out.

\section{Table 11: Kao Residual Co-integration Test output.}

Kao Residual Cointegration Test

Series: $D(R O E) D(P O S) D(M P A Y) D(W P A Y) D(A T M)$

Date: 12/06/19 Time: 01:02

Sample: 20072018

Included observations: 192

Null Hypothesis: No cointegration

Trend assumption: No deterministic trend

Automatic lag length selection based on SIC with a max lag of 1

Newey-West automatic bandwidth selection and Bartlett kernel

\begin{tabular}{|c|c|c|}
\hline & $\mathrm{t}$-Statistic & Prob. \\
\hline ADF & -5.046418 & 0.0000 \\
\hline Residual variance & $1.38 \mathrm{E}+14$ & \\
\hline HAC variance & $8.93 E+13$ & \\
\hline
\end{tabular}

Augmented Dickey-Fuller Test Equation

Dependent Variable: D(RESID)

Method: Least Squares

Date: 12/06/19 Time: 01:02

Sample (adjusted): 20112016

Included observations: 90 after adjustments

\begin{tabular}{lrllr}
\hline \hline \multicolumn{1}{c}{ Variable } & Coefficient & Std. Error & t-Statistic & Prob. \\
\hline \hline \multicolumn{1}{c}{ RESID(-1) } & -0.957383 & 0.106700 & -8.972693 & 0.0000 \\
\hline \hline R-squared & 0.474657 & Mean dependent var & -294461.3 \\
Adjusted R-squared & 0.474657 & S.D. dependent var & 12439533 \\
S.E. of regression & 9016239. & Akaike info criterion & 34.87800 \\
Sum squared resid & $7.24 \mathrm{E}+15$ & Schwarz criterion & 34.90578 \\
Log likelihood & -1568.510 & Hannan-Quinn criter. & 34.88920 \\
Durbin-Watson stat & 2.105145 & & \\
\hline \hline
\end{tabular}

The above Error Correction estimate shows that the out of equilibrium model can be adjusted back to equilibrium by $20.2 \%(-0.202982)$. This is upheld based on the anticipated negative assigned coefficient of the Error Correction estimate (CointEq1). Which is seen to be significant as the t-statistics of -2.31752 is greater than $-/+1.98$ or 2 . The long run coefficient shows that subject to variations, only Point of Sale (POS) expenditure (POS), and Automated Teller Machine (ATM) showed significant t-statistics of -2.01938 , and 17.7481 respectively. 
This shows that in the long run, Point of Sale (POS) expenditure and Automated Teller machine (ATM) represents fundamental factors that Positively stimulates profitability of financial institutions in Nigeria while

In light of long run relationship, the above Augmented Dickey Fuller t-statistics value of 5.046418 at a probability level of 0.000 which is less than the $5 \%$ significance level shows a great evidence in support of the existence of a long run relationship between employed variables. This shows that, there is evidence of similarities in trend between employed variable amidst variations and shocks in the immediate financial environment.

Implication: Economically speaking, this implies that there is existence of long run relationship in the model. The presence of co-integrating relationship depicts that the variables share mutual stochastic trend and are connected in a common long-run equilibrium. We can then conclude that all the model variables have long-run equilibrium relationship. The implication of this, the researcher reasoned, is that, if the DMBs can harness and exploit the opportunities and the full benefits which e-products modeled in this study offer, by adopting appropriate technology upgrading, robust network connectivity, awareness creation and sensitization of the these e-products to the customers, it will leap-frog their profitability performance in the long-run thereby confirming the findings of Hernando and Nieto (2007) on increased profitability performance at long run. Also, from the Unit Root Tests, the regression residuals were found to be stationary at level (1). This confirms that all the variables are perfectly co-integrated.

\section{Panel Error Correction Model}

To adjust for discrepancies between the long and short run equilibrium, the study carries out the error correction model as follows;

Table 12: Error Correction Model Estimate Test output.

\section{Vector Error Correction Estimates}

Date: 12/06/19 Time: 01:03

Sample (adjusted): 20092018

Included observations: 160 after adjustments

Standard errors in ( ) \& t-statistics in [ ]

\begin{tabular}{ccc}
\hline \hline Cointegrating Eq: & CointEq1 \\
\hline \hline ROE(-1) & 1.000000 & \\
& 0.000530 \\
POS(-1) & $(0.00026)$ & \\
& {$[2.01938]$} & \\
& 497.0501 & \\
ATM(-1) & $(28.0059)$ & \\
& {$[17.7481]$} & \\
C & -69516438 & \\
\hline \hline
\end{tabular}


Journal DOI: www.doi.org/10.46654/RJMP

Vol. 7, Issue 3 (March, 2021) | www.ijaar.org

Article DOI: $\underline{\text { www.doi.org/10.46654/RJMP.7325 }}$

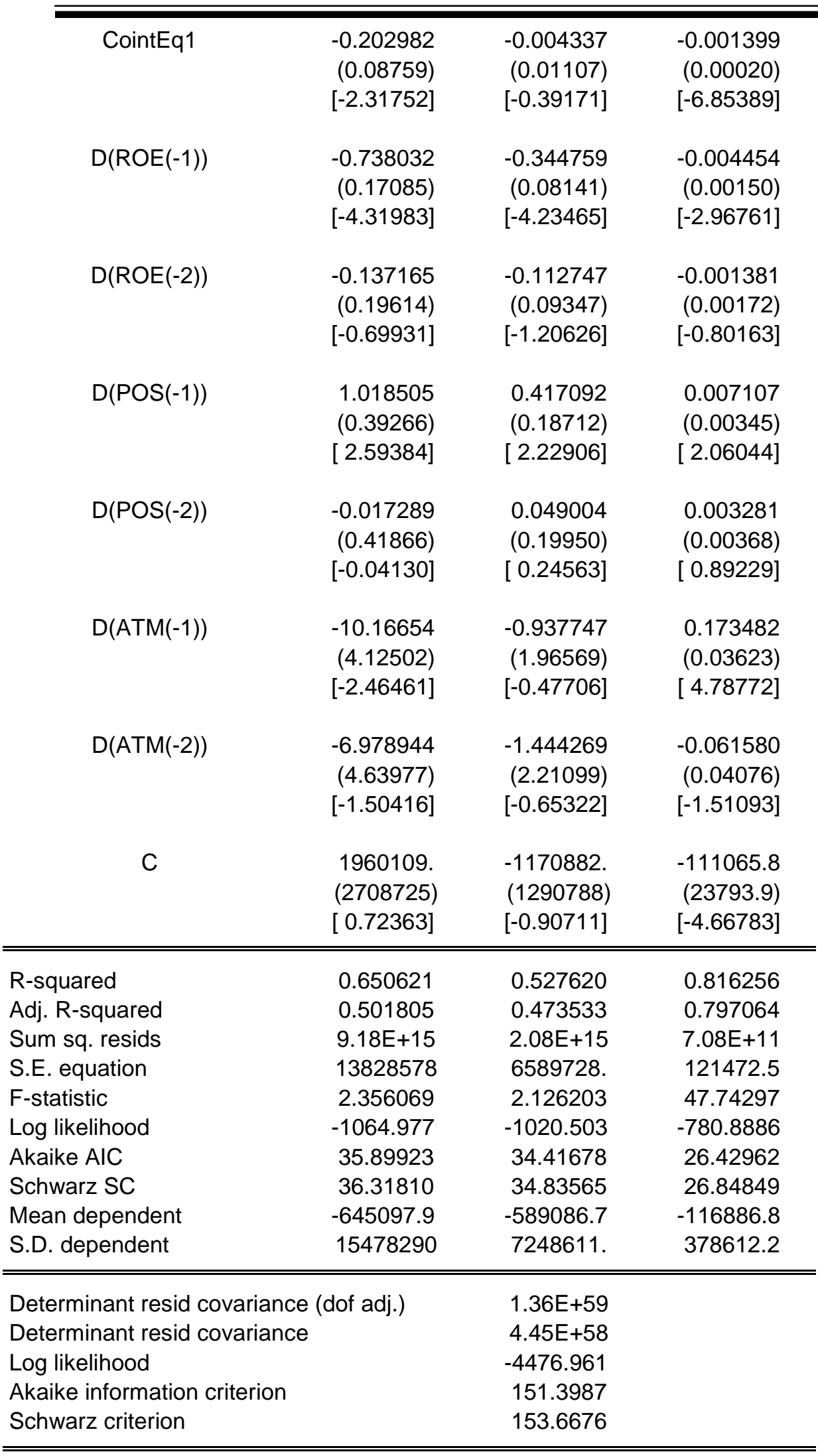

The above Error Correction estimate shows that the out of equilibrium model can be adjusted back to equilibrium by $20.2 \%(-0.202982)$. This is upheld based on the anticipated negative assigned coefficient of the Error Correction estimate (CointEq1). Which is seen to be 
significant as the t-statistics of -2.31752 is greater than $-/+1.98$ or 2 . The long run coefficient shows that subject to variations, only Point of Sale (POS) expenditure (POS), and Automated Teller Machine (ATM) showed significant t-statistics of -2.01938, and 17.7481 respectively. This shows that in the long run, Point of Sale (POS) expenditure and Automated Teller machine (ATM) represents fundamental factors that positively stimulates profitability of banks in Nigeria

In summary; the study discovers a positive and significant influence of Point of Sale (POS) Expenditure on Return on equity in the selected financial institutions. And it is seen that there existed a positive and significant influence of Automated Teller Machine on Return on equity in the selected financial institutions.

\section{Stacked Pairwise Granger causality test}

To evaluate for causal relationship between the employed variables, the following evaluation is presented as follows;

\section{Table 13: Pairwise Granger Causality Test output.}

Pairwise Granger Causality Tests

Date: 12/06/19 Time: 00:59

Sample: 20072018

Lags: 2

\begin{tabular}{lccc}
\hline \hline Null Hypothesis: & Obs & F-Statistic & Prob. \\
\hline \hline (POS) does not Granger Cause (ROE) & 75 & 6.61020 & 0.0023 \\
(ROE) does not Granger Cause (POS) & & 10.4563 & 0.0001 \\
\hline \hline & & & \\
\hline \hline (ATM) does not Granger Cause (ROE) & 75 & 1.97296 & 0.1467 \\
(ROE) does not Granger Cause (ATM) & & 0.78165 & 0.4616 \\
\hline \hline
\end{tabular}

The stacked pair wise Causality test shows the presence of bidirectional causal relationship between Point of Sale (POS) expenditure (POS) and Portability of employed financial institutions (ROE). This shows that more is expended on the salaries, wages and allowances of workers when profit rising. And also firms try to make profit rise by increasing the salaries, wages and allowances of workers. Unidirectional Causality is seen to spill from Point of Sales(POS) to profitability of employed firms. This shows that firms usually have to put supportive infrastructures in place before witnessing its effect on profits. All other variables show negligible causal relation to profitability.

Implication of the result: The result implies that if Deposit Money Banks invest heavily in e-Products (especially Point of sales and Mobile Pay), robust Information Technology, it will enhance their profitability performance. On the converse, the DMBs has been and will have to plough back part of the profit on IT Acquisitions and upgrading, procurement of more Automated Teller Machines, Point of Sale devices and general enhancement of internet banking systems that will guarantee higher and sustainable returns. This result confirms the findings of AL-Sukkar (2005) and Aladwani (2001) in their respective investigations. 


\section{Hypotheses Testing}

$\mathbf{H}_{01}$ : There is no significant relationship between Point of Sale (POS) and Return on equity of deposit money banks in Nigeria.

The Error correction Model coefficient of 0.000530 shows a positive sign and its t-statistics of 2.01938 which is seen to be greater than the standard tabulated value of \pm 1.98 or 2 leads to the rejection of the null hypothesis. The study thus concludes that there is a significant relationship between Point of Sale (POS) and Return on equity of deposit money banks in Nigeria.

Thus empirical results is in agreement with the empirical findings of Abaenewe., Uche and Faith (2013), Balaji and Balaji (2017), Jumba and Wepakhulu (2019) in Nigeria.

$\mathbf{H}_{\mathbf{0 2}}$ : There is no significant relationship between Automated Teller Machine (ATM) and Return on equity of deposit money banks in Nigeria.

The Error correction Model coefficient of 497.0501 shows a positive sign and its t-statistics of 17.7481 which is seen to be greater than the standard tabulated value of \pm 1.98 or 2 leads to the rejection of the null hypothesis. The study thus concludes that there is a significant relationship between Automated Teller Machine (ATM) and Return on equity of deposit money banks in Nigeria.

However, these empirical findings were not in conformity with the empirical results of Le., Vu., Du and Tran (2018), Mahboub (2018), Mustapha (2018) in China, Ghana and Nigeria.

\section{Concluding Remark and Recommendations}

For businesses, successful e-payment products rely on internal and external factors. To improve its internal factors; readiness such as the level of resources, awareness, commitment, governance, as well as its business strategy, a company needs its management to take a proactive and open view towards e-payment. The quantitative analysis results revealed that epayment products significantly and positively relate to quoted deposit money banks performance in Nigeria.

Based on the above findings and concluding remark, we recommend that;

i) Automated Teller Machine (ATM) should be put in different locations for easily accessible by customers, so that quick service and convenience is maintained hence improving bank operations to the same time constant service should be ensured in order to provide reliability of the services.

ii) Deposit money banks and other specialized organizations should conduct awareness programs for client son the importance and ease of using electronic payment products in financial transactions in local and international markets.

iii) Banks should pay attention to issuing new and modern electronic payment methods to attract new customers and fellow developments in global markets. 
Journal DOI: www.doi.org/10.46654/RJMP

Vol. 7, Issue 3 (March, 2021) | www.ijaar.org

Article DOI: $\underline{\text { www.doi.org/10.46654/RJMP.7325 }}$

\section{Limitation and Suggestion for Further Studies}

While this empirical study ahs produced interesting findings, it also has some imitations. We investigated the relationship between e-payment products and quoted deposit banks performance using point of sale (POS) and automated teller machine (ATM) spanning from 2007-2018 based on country specific empirical datasets, this fact may nevertheless limit the findings' generalisability. Further studies both in developed and less developing countries should use more sub-variables of e-payment products and performance of deposit money banks spanning from 2007-2018. 


\section{REFERENCES}

Abaenewe, A., Uche. T. O., \& Faith, M. K. (2013). Electronic banking and bank performance in Nigeria: West African Journal of Industrial and Academic Research, 6(1), 27-41.

Aburine, T. U. (2008). Determinants of bank profitability: Macroeconomic evidence from Nigeria, Deaken University, working paper, p1-10

Abutaleb, A. \& Hashem, A. (2001). The Impact of Information and communication technology (ICT). on economies of some MENA Countries. Telematics and Informatics. 14(3), 273- 288.

Afolabi (2009). The role of information technology in Nigeria. A case study of intercontinental bank, Guaranty Trust Bank and First Bank.

Agboola, A.A. (2001). Impact of electronic banking on customer services in Lagos, Nigeria, Ife Journal of Economics and Finance, 5(1\&2), 29-32, 7-11.

Agwu, E. (2012). A qualitative study of the problems and prospects of online banking in developing economies-Case of Nigeria. Available at SSRN 3112130.

Akhisar, İ., Tunay, K. B., \& Tunay, N. (2015). The effects of innovations on bank performance: The case of electronic banking services. Procedia-Social and Behavioral Sciences, 195, 369-375.

Akinlo, W.T. (2010). Business behaviour, value and growth. New York: Mac Millan.

Akinyomi, O.J., \& Adebayo, O. (2013). Effect of firm size on profitability: Evidence from Nigerian manufacturing sector. Prime Journal of Business Administration and Management (BAM), 3(9): 1171-1175.

Aladwani, A. (2001). Online banking: A field study of drivers, developing challenges, and expectations, International Journal of Information Management,21(1), 213-225

Alhajri, S. (2008). The adoption of e-payment :The case of Omani Bank. International Review of Business Research Papers, 4(5),120-128.

Al-Smadi, M.O.,\& Al-wabel, S.A. (2011). The Impact of electronic banking on the financial performance of jordan bank: Journal of internet banking and commerce. 16(2),35-49

Al-Sukkar, H. (2005). Toward a model for the acceptance of internet banking in developing countries. Information Technology for Development, 11(4), 381-398

Amedu, U.M. (2005). Domestic electronic payment in Nigeria: The Challenge. Central Bank of Nigeria Bulletin, 9(1),40-48

Amiri, S. \& Reif, B. (2013). Internet penetration and its correlation to gross domestic product: An analysis of the Nordic countries. International Journal of Business, Humanities, and Technology, 3(2), $50-60$.

Anyanwokoro, M. (1999). Theory and policy of money and banking, Enugu: Hossana publication 
Aranyossy, M. (2018). Citizen adoption of e-government services - Evidence from Hungary. Digital Transformation - Meeting the challenges. doi:10.18690/978-961-286-170-4.3

Ashaolu, O.J. (2004). E-commerce and banking performance in Nigeria, Academia, Inc. www.academia.edul

Balachandher, K.G. (2001). Electronic banking in Malaysia: A note of evolution of services and consumer relations, Malaysia, Multimedia University.

Balaji, K. C., \& Balaji, K. (2017). A study on demonetization and its impact on cashless transactions. International Journal of Advanced Scientific Research \& Development, 4(3), 58-64.

Balimoune, M. N. (2002). The new economy and developing countries: Assessing the role of ict diffusion, WIDER Discussion Paper, No. 2002/77

Basel Committee on Banking Supervision (2003). Risk management principles for electronic banking, Switzerland Bank for International Settlements. Retrieved $10^{\text {th }}$ July, 2010 from http://www.bis/pub/bcbs/pdf

Bátiz-Lazo, B. (2018). Epilogue: The cashless economy and the ATM. Oxford Scholarship Online. doi:10.1093/oso/9780198782810.003.0010

Bayes, A. (1999). Village pay phones and poverty reduction: Insights from a Grameen bank initiative in Bangladesh, ZEF - Discussion Paper on Development Policy 8(7), 7-9.

Bebee, E. L. \& Gilling, E. T. W. (1967). Telecommunications and economic development: A model for planning and policy making, International Telecommunications Society, Sydney.

Bertonèche, M., \& Knight, R. (2003). Financial performance. Oxford: ButterworthHeinemann.

Bilgihan, A. (2016). General customer loyalty in online shopping: An integrated model of trust, user experience and branding. Computers in Human Behavior, 61(8), 103-113.

Braga, C., (1998). Inclusion or exclusion? UNESCO Courier. Duke Journal Comp. \& Int'l L., 9(1), 163-170.

Brown, M. M., (2001). Can ICTs address the needs of the poor?: A commentary from UNDP, June 2001

Burr, W.,\& Lustsik, O. (2004). CanE-payment Services be Profitable? Estonia, Tartu University Press.

Carvalcio, T.,\& Siegel, M. (2011). Return on Investment: An analysis of financial account aggregation, MIT Sloan School of Management working paper 4384-02

Castells, M. (2000). The rise of the network society. Oxford: Blackwell $2^{\text {nd }}$ Edition.

Central Bank of Nigeria (2002). Nigeria Automated Clearing System (NACS)/ Publications on Quest for Alternative Payment Systems.

Central Bank of Nigeria (2003). Guidelines on Electronic Banking in Nigeria.

Central Bank of Nigeria (2012). Reports/ Guidelines on Debit Cards.

Central Bank of Nigeria (2012). Reports on Cashless Policy. 
Central Bank of Nigeria. (2017). Publications. Nigeria: Abuja.

Chalomba, N., \& Gujral, M. (2016, July). Consumer perceptions and adoption of mobile payments in Johannesburg, South Africa: A Case of University Students. In 2016 Global Marketing Conference at Hong Kong (pp. 1310-1327).

Chowdhury, N., (2000). Poverty alleviation and information and communication technologies, Dec. 2000. Towards a Motif for the United Nations ICT Task Force, http://www.eb2000.org/shortnote19.htm.

Cocosila, M., \& Trabelsi, H. (2016). An integrated value-risk investigation of contactless mobile payments adoption. Electronic Commerce Research and Applications, 20, 159170.

Cronin, J. et al. (2002). The contribution of telecommunications infrastructure to aggregate and sectoral efficiency, McGraw-Hill, New York.

Daniel, E. (1999). Provision of electronic banking in the U.K. and the republic of Ireland: International Journal of bank marketing, 17(2), 72-82

Delgado, J., Hernando,I.,and Nieto, M.J. (2007). Do European primary European Financial Management internet banks show Scale experience efficiencies? 13(4), 643-671.

De-Young, R. (2007). How the Internet affects the output and performance at community banks, Journal of banking and finance, 31(1), 1033-1060.

Dogarawa, A.B. (2005). The impact of e-payment on customer satisfaction in Nigeria htt://mpra.ub.uni-muenchen.de/23200/Sept.15 2013

Ekwueme, O. (2012). An empirical assessment of the operational efficiency of the electronic banking: Evidence of Nigeria Banks. Review of Public Administration and Management, 1(2), 108-132.

Fonchamnyo, D.C. (2013). Customers' perception of e-payment adoption in Cameroon: An Empirical Assessment of an Extended TAM. International Journal of Economics and Finance, 5,(1), 166-176

Gardade, K. D. \& Silber, W. L. (1978). Technology, Communication and the Performance of Financial Markets. (1840-1975). Journal of Finance, 33(3), 819-832.

Gerpott, T. (2018). Experienced speeds of fixed Internet connections as drivers of customer bonds with their provider-An empirical study of consumers in Germany. Management ScienceLetters, 8(12), 1239-1258.

Gertignon, S. (2008). Is Internet banking in India consumer concern and economic growth: Evidence from Nigeria data Asian economic and financial review, 3 (1), 75-98.

Greenan N, \& Guellec, D. (1997). Technological innovation and employment reallocation. INSEE Mimieo.

GSM Association (2018). Sustaining growth and innovation in the mobile industry across West Africa. www.gsma.com.

Gujarati Basic Econometrics, $5^{\text {th }}$ (ed)Palgrave Macmillan, London.

Gurley, J.G., \&Shaw, E.S. (1960). Money in a theory of finance. Washington D.C., Brooklin Institution Press. 
Han, S., Keys, B., \& Li, G. (2015). Information, contract design, and unsecured credit supply: Evidence from credit card mailings. Finance and Economics Discussion Series,2015(103), 1-54. doi:10.17016/feds.2015.103

Hardy, A. P., (1980). The role of the telephone in economic development, Telecommunications Policy, Elsevier, 4(4), 278-286.

Harrison R, Jordi J, Jacques M, \& Bettina, P. (2006). Does innovation stimulate employment? A firm level analysis using comparable micro data from four countries. Available at: $\underline{w w w . c r e s t . f r}$.

Hasan, I., De Renzis, T., \&Schmiedel, H. (2015). Retail payments and economic growth. SSRN Electronic Journal. doi:10.2139/ssrn.2100651

Hastomo, A. D., \& Aras, M. (2018). Influence of Cashless Society Socialization toward Trust Transaction Culture in Jakarta, Indonesia. Humaniora, 9(1), 1-13.

Hennart, J. F. (1993). Explaining the swollen middle: Why most transactions are a mix of market and hierarchy. Organization science, 4(4), 529-547.

Hernando, I. and Nieto, M.J. (2007). Is the internet delivery channel changing bank's performance? The case of Spanish Banks, Journal of Banking and Finance, 31(1), 1083-1099

Ighobor, K. (2017). Africa's quest for a cashless economy gains momentum. Africa Renewal, $31(1), 16-17$.

Igwe, U. O. (2205). Harnessing information technology for the $21^{\text {st }}$ century. Library Education in Nigeria, library philosophy and practice. 7(2). 12 -13.

Imiefoh, P. (2012). Towards effective implementation of electronic banking in Nigeria: African Research Review, 6(2), 35-41,

International Telecommunications Union (ITU). (2017). Facts and figures. https://www.itu.int/en/ITU-D/Statistics/Pages/stat/default.aspx.

Jain, P. (2017). Cashless system of colleges in India. International journal of social sciences andhumanities, 1(3), 1-7.

James, A.O. (2012). The Acceptance of e-payment by customers in Nigeria: World Review of Business Research, 2(2), 6-8

Jason, L., \& Glenwick, D. (Eds.). (2016). Handbook of methodological approaches to community-based research: Qualitative, quantitative, and mixed methods. Oxford university press.

Javala, J. \& Pohjola, M. (2002). Economic growth in the new economy. Evidence from Advanced Economies, Information Economics and Policy, 14, No. 2, June.

Jipp, A., (1963). Wealth of Nations and Telephone Density, Telecommunications Journal, July.

Jourgenson, D. W. \& Stiroh, K. J. (1999). Information technology and growth. American Economic Review, 91(1). 1-32.

Juariah, R. (2015, May). Innovation green banking in banking service (electronic banking) to improve quality. In International Conference on Economics and Banking (iceb-15). Atlantis Press. 
Jumba, J., \& Wepukhulu, J. M. (2019). Effect of E-payments on the financial performance of Nigerian banks. International Journal of Academic Research Business and Social Sciences, 9(3), 1372-1397.

Kaplan, D. (2001). Defining the information society, initial preparatory workshop, united nations world summit on the Information Society, Coppet, Switzerland, 5-6 December.

Kellner, D. (1999). New technologies and alienation: Some critical reflections. https://pages.gseis.ucla.edu/faculty/kellner/essays/technologyalienation.pdf

Khrawish, H.A.,\& Al-Sadi, A. (2012). The Impact of E-payment on Bank Profitability: European Journal of Business and Social Sciences, 2(9), 186-201

Kondabagil, J. (2007). Risk management in electronic banking: Concept and Best Practices, India, John Wiley \& Sons.

Kosse, A., Chen, H., Felt, M. H., Jiongo, V. D., Nield, K., \& Welte, A. (2017). The costs of point-of-sale payments in canada (No. 2017-4). Bank of Canada Staff Discussion Paper.

Kramer, W. J., Jenkins, B \& Katz, R. B. (2007). The role of the Information and Communications Technology sector in expanding economic opportunity. Corporate Social Responsibility Initiative Report No. 22, Kennedy School of Government, Harvard University, Cambridge, MA.

Kumar, L. (2016). Can Mobile Money Replace Cash in India?. In The Book of Payments (pp. 297-310).

Lachenmaier S, Rottmann H (2007). Effects of innovation on employment: a dynamic panel analysis. Journal of Industrial Organization. Elsevier, pp: 210-220.

Laudon, K. C., \& Laudon, J. P. (2015). Management Information Systems: Managing the Digital FirmPlus MyMISLab with Pearson eText--Access Card Package. Prentice Hall Press.

Le, H. L., Vu, K. T., Du, N. K., \& Tran, M. D. (2018). Impact of working capital management on financial performance: The case of Vietnam. International Journal of Applied Economics, Finance and Accounting, 3(1), 15-20.

Leff, N. H., (1984). Social Benefit-Cost Analysis and Telecommunications Investment in Developing Countries, Information Economics and Policy, 1. September, 217-227.

Lustik, O. (2004). Can E-payment be profitable? Estonia, Tartu University Press.

MacKenzie, D. A. (1996). Knowing machines: Essays on technical change (inside technology). MIT Press.

Madden, G., Savage, S., \& Simpson, M. (1997). Regional Information Access: The Use of Telecentres to Meet Universal Services Obligations, Telematics and Informatics. 14(3), 273- 288.

Madueme, I. S. (2010). Evaluation of the impact of information communication technology on banking efficiency using transcendental logarithmic production function and CAMEL rating, International Journal of Engineering Science and Technology, 2,(1), 16 
Maduka ,A.C.,\& Onwuka, K.O. (2013). Financial Market Structure and Electronic Banking in NigeriaChanging Bank Strategies? Global Journal of Business Research, 2, No.1, p43-51

Mahboub, R. M. (2018). The Impact of Information and Communication Technology Investments on the financial performance of Lebanese Banks. European Research Studies Journal, 21(4), 435-458.

Mahran, A. F., \& Enaba, H. M. L. (2011). Exploring determinants influencing the intention to use mobile payment service. International Journal of Customer Relationship Marketing and Management (IJCRMM), 2(4), 17-37.

Maiyaki, A.U.,\& Moktar, S.U. (2010). Effects of Electronic Banking Facilities, Employment Sector and Age-group on Customer's Choice of Banks in Nigeria, Journal of International Banking and Commerce, 15(1), 7-11.

Malhotra, P. and Singh, B. (2009). Experience in Internet Banking and Performance of Banks", International Journal of Electronic Finance,4(1), (http://www.inderscience.com)

Mansell, R. \& When, U. (1998). Knowledge Societies: Information Technology for Sustainable Development, Prepared for United Nations Commission on Science and Technology for Development, Oxford University Press, Oxford.

Marinč, M. (2013). Banks and information technology: marketability vs. relationships. ElectronicCommerce Research, 13(1), 71-101.

Martin, B. (2001). Technology for nonviolent struggle. London War Resisters' International. https://www.uow.edu.au/ bmartin/pubs/01tnvs/tnsa.pdf.

MasterCard. (2014). Cashless Journey: Tracking the Global Shift to Cashless Societies | Global Hub. Retrieved from https://newsroom.mastercard.com/digital-presskits/cashless-journey-tracking-the-global-shift-to-cashless-societies/

Matteucci N., \& Sterlachini, A. (2003). Informational and communicational technology and employment growth in Italian industries. Retrieved online at: http://www.niesr.ac.uk/research/epke/wp-17.pdf

Merikull, J. (2008). The impact of innovation on employment: firm and industry level evidence from Estonia. Eesti bank (Bank of Estonia).

Merton, R.C. (1989). On the application of Continuous-time Theory of Finance to Financial Intermediation and Insurance. Geneva Papers on Risk and Insurance Theory, 14, p225261

Migdadi, Y.K. (2008). The Quality of internet banking services encounter in Jordan. Journal of Internet Banking and Commerce, 13(3), p1-8.

Mohammad, A.O.,\& Saad, A.A. (2011). Impact of E-payment on the financial performance of Jordan Banks. Journal of InternetBanking and Commerce, August 2011,16, No.30

Moradi, M. A., \& Kebryaee, M. (2010). Impact of information and communication technology on economic growth in selected Islamic countries. Quarterly Journal of New Economy and Commerce. 2(3), 121-139.

Mugambi, A., Njunge, C., \& Yang, S. C. (2014). Mobile-money benefits and usage: the case of ELECTRONIC BASED PAYMENT. IT Professional, 16(3), 16-21. 
Muhammad, A., \& Kebbi, H. S. B. (2014). Impact analysis of information and communication technology on finance and economic growth in Nigeria (20012011). European Scientific Journal, ESJ, 10(1).

Munjeyi, Edmore, Chiwira, Oscar, Maponga, Stephen, Samson. (2017). The Cashless Economy inZimbabwe: The Golden Time to Tax the Informal Sector. The International Institute forScience, Technology and Education (IISTE.

Mustapha, S. (2018). E-Payment Technology Effect on Bank Performance in Emerging Economies-Evidence from Nigeria. Journal of Open Innovation: Technology, Market, and Complexity, 4(4), 43.

Nandi, B. \& Dholakia, J. (1994). Role of Telecommunications in Developing Countries in the 21st century, Seoul: International Telecommunications Society (ITS). 14th Biennial Conference Paper.

Nasab, E. H., \& Aghaei, M. (2009). The effect of ICT on economic growth: Further evidence. International Bulletin of Business Administration, 5(2), 46-56.

Ndukwe, E. (2003). The challenges of globalization and the imperative of creating adequate ICT infrastructure in Nigeria. A paper presented at the e-Nigeria 2003 International Conference on Information and Communications Technologies (ICTs).

Ndukwe, E. (2004). The role of telecommunications in national development. Nigerian Tribune, No. 13, Tuesday, September 21.

Nikolai, L.,\& Bazlay, J.D. (1997). Intermediate Accounting: Ohio, South-Western College Publishing.

Nithin, M., Jijin, P., \& Baiju, P. (2018). Has Demonetisation Pushed Digitalisation in India? Some Counter Evidences. Journal of Business Thought, 9, 58-69.

O'Mahony, M., Robinsonb, C., \& Vecchi, M. (2008). The Impact of ICT on the demand for skilled labor: a cross- country comparison. J. Labor Econ. Elsevier lt. 1435-1450.

Obehioye, A.H., \& Osahon, O.H. (2013). Creative accounting and firm's market value in Nigeria. Arabian Journal of Business and Management Review, 2(3): 38 - 50.

Oju, O. \& Onyebuka, C. (2015). ICT for Sustainable Economic Development and Growth in Rural Areas. International Journal of Computer Science and Mathematical Theory. 2(1). 55-66.

Okoro, A. S. (2014). Impact of Electronic Banking Instruments on the Intermediation Efficiency of the Nigerian Economy International Journal of Accounting Research, 1, No.6.

Oliner, S. \& Sichel, D. (2000). The Resurgence of Growth in the Late 1990s: Is Information Technology the Story? Working Paper, Federal Reserve Board, Washington D. C. USA.

Olofin, B. B. \& Aniede, P. I. (2016). Challenges and barriers to ICT deployment in Nigerian Universities. : https://www.researchgate.net/publication/303810498, November.

Olorunsegun, S. (2010). Impact of electronic banking in Nigeria banking system, MBA Research Project submitted to Department of Management Science, Faculty of Engineering and Technology, Ladoke University, Oyo State, p23-29

Omotayo, G. (2007). A Dictionary of finance, West Bourne, England: West Bourne Business School. 
Onay, C., Ozsoz,H. and Ash, D.(2008). The Impact of Internet Banking on Banks Profitability: The case of Turkey. OxfordBusiness and Economics Program, June 2224.

Osei-Assibey, E. (2015). Mobile Money and Financial Inclusion. Financial Inclusion for PovertyAlleviation, 118-135. doi:10.9774/gleaf.9781315103457_9

Ovie, J. (2001). Internet Banking: practice and potentials in Nigeria. Paper delivered at a Workshop organized by ICAN at Lagos.

Oyeniran, W. I. \& Onikosi-Alliyu, D. (2016). Information and Telecommunication infrastructure and economic growth: An experience from Nigeria. Serbian Journal of Management, 11(22), $275-289$.

Pesaran, M. H., Shin, Y., \& Smith, R. J. (2001). Bounds testing approaches to the analysis of level relationships. Journal of applied econometrics, 16(3), 289-326.

Pohjola, M. (2001). Cross-Country Diffusion of the Internet, Information Economics and Policy, 13(1), 297-310.

Porter, T. (Ed.). (2014). Transnational financial regulation after the crisis. Routledge. Rafique, M., Rizwan, M., Batool, A., \& Aslam, F. (2014). Extending TAM, in terms of Trust and Attitude towards the online shopping intention. Journal of Public Administration andGovernance, 4(3), 90-108.

Posu, S. M. A. (2006). Information and communication technologies in the Nigerian economy. In International Conference on Human and Economic Resources, Technology. 327-337.

Rabiu, I. D., Ladan, S., Usman, H. A., \& Garba, M. (2019). Impact of E-banking on the Operational Efficiency of Banks in Nigeria. International Journal of Academic Research in Business and Social Sciences, 9(2).

Raymond, V. \& Zhen, N. (2016). Dynamics of Technological innovation and employment: Panel evidence from Luxembourg. International Journal of Innovative Research and Development. 5(6), 500-518.

Ringim, K. J., Razalli, M. R., \& Hasnan, N. (2012). A framework of business process reengineering factors and organizational performance of Nigerian banks. Asian Social Science, 8(4), 203.

Rogers, E. M. (1995). Diffusion of Innovations (4th Eds.). ACM The Free Press (Sept. 2001). New York, 15-23.

Rogers, E.M. (1995). Diffusion of Innovation: $4^{\text {th }}$ (ed), New York, The Free Press.

Rogoff, K. (2015). Costs and benefits to phasing out paper currency. NBER MacroeconomicsAnnual, 29(1), 445-456.

Rooach, S. S. (1991). Services under siege: The restructuring of imperative. Harvard Business Review 392, 82-92.

Rose, P.S. (2001). Cmmercial Bank Management: $5^{\text {th }}$ (ed), New York, McGraw-Hill Irwin.

Roy, A. (2018). Business impacts of electronic banking technologies. International Journal ofElectronic Banking,1(2), 113. doi:10.1504/ijebank.2018.10016639 
Saarijärvi, H., Mitronen, L., \& Yrjölä, M. (2014). From selling to supporting-Leveraging mobile services in the context of food retailing. Journal of Retailing and Consumer Services, 21(1), 26-36.

Saragih, J. L. (2018). The Effects of Return on Assets (ROA), Return on Equity (ROE), and Debt to Equity Ratio (DER) on Stock Returns in Wholesale and Retail Trade Companies Listed in Indonesia Stock Exchange. International Journal of Science and Research Methodology, 8(3), 348-367.

Sathye, M. (1999). Adoption of Internet Banking by Australian Consumers: an empirical investigation, International Journal of bank marketing, 17(7), p324-334

Sathye, M. (2005). The impact of internet banking on performance and risk profile: Evidence from Australian credit unions. Journal of Banking Regulation, 6(2), p163-174.

Sepehrdoust, H., \& Khodaee, H. (2013). The Impact of Information and Communication Technology on Employment of Selected OIC Countries. African Journal of Business Management, 7(39), 4149-4154.

Shagari, S. L., Abdullah, A., \& Saat, R. M. (2017). Contributory factors of accounting information systems effectiveness in Nigerian banking sector. Asian Journal of Multidisciplinary Studies, 151.

Shukla, U. N. (2017). An empirical study on future of mobile-wallets in India: A gateway for cashless payments. Arthshastra: Indian Journal of Economics \& Research, 6(6), 51-62.

Shuqair,A. (2003). Practical Electronic Banking Services by Jordanian Banks.

Siam, A.Z. (2006). Role of Electronic Banking Services on the profiles Jordanian Banks, American Journal of Applied Sciences, 3(9), 1999-2004

Simpson, J. (2002). The Impact of the Internet in Banking: Observations and Evidence from Developed and Emerging Markets. Telematics and Informatics,19, p315-330

Singh, R. \& Roy, S. (2015). Asian Journal of Research in Business Economics and Management, 5, No. 1, pp. 12-18

Smith, M. R. \& Marx, L. (1994). Does technology drive history? The dilemma of technological determinism. MIT Press. Cambridge, Massachussett.

Son, I., \& Kim, S. (2018). Mobile Payment Service and the Firm Value: Focusing on both Up-and Down-Stream Alliance. Sustainability, 10(7), 2583.

Stanley, T. D., Doucouliagos, C. \& Steel, P. (2015). Does ICT generate economic growth? A Meta-regression analysis, Deakin University Australia, School Working paper, Economics series SWP 2015/9.

Tee, H. H., \& Ong, H. B. (2016). E-payment and economic growth. Financial Innovation, $2(1), 4$.

Theophilus, B., Ifionu, E. P., \& Nnamdi, I. S. (2018).ICT Correlates and Economic Growth In Nigeria.

Thomas, H., Jain, A., \& Angus, M. (2013). Measuring progress toward a cashless society. MasterCardAdvisors. 
Tilakaratna, G. (2016). Financial Inclusion in Sri Lanka: Current Status and Issues. In FinancialInclusion in Asia (pp. 187-208). Palgrave Macmillan, London.

Tomas, F., Diaz, M. (2002). Technological innovation and employment: data from a decade in Spain. J. Prod. Econ. Elsevier pp.245-256.

Trajhova, N. (2005). Global Finance Names the World Best Internet Bank in the Middle East and Africa (online-www.http/)

Uguru, U., Hemen, P., \& Atuba, F. D. O (2016). The Role of Innovation in the Economic Development of Nigeria. International Journal of Innovative Research and Development. 5(6), 500-518.

United Nations Conference on Trade and Development (UNCTAD 2002). and Hertzum et al(2004). World Investment Report 2002, New York and Geneva.

Upadhyay, P., \& Jahanyan, S. (2016). Analyzing user perspective on the factors affecting use intention of mobile based transfer payment. Internet Research, 26(1), 38-56.

$\mathrm{Vu}, \mathrm{K}$. (2004). Measuring the impact of ICT investments on economic growth. JEL Classification, 3(1), 4-12.

Williamson, O. E. (1993). Calculativeness, trust, and economic organization. The journal of law andeconomics, 36(1, Part 2), 453-486.

Williamson, O. E. (1993). Opportunism and its critics. Managerial and decision economics, 14(2), 97-107.

WorldBank.(2016). Financial Access. Retrieved from http://www.worldbank.org/en/publication/gfdr/gfdr-2016/background/financial-access

Worlu, R. E., Olokundun, A. M., Akinbode, M., Amaihian, A. B., \& Inelo, F. (2016). Stress arising from work roles and impediments to organizational performance. Research Journal of Medical Sciences, 10(1), 1-5. 